\title{
Tarihsel Gelişim Süreci İçinde Anadolu'daki Yerleşimler ve Konut Tipolojileri Üzerine Bir Değerlendirme
}

\author{
Çiğdem TUĞAÇ ${ }^{1}$
}

Öz

Geçmişten günümüze insanlar, içinde yaşadığı dünyayı şekillendirmek ve değiştirmek istemişlerdir. Bu yaklaşımın temelinde başlangıçta hayatta kalma, barınma, korunma ve çoğalma gibi ihtiyaçlar olsa da ilerleyen dönemde doğaya hâkim olma, üretme, gelişme ve güç elde etme gibi isteklerin öncekilere eklenmesiyle insan eylemleri, mekânın şekillenmesinde başat unsurlardan biri haline gelmiştir. İnsanlık mekânı, yaşadığı yerleşimleri ve onun içinde konutu şekillendirmiş; bunu yaparken de çevresel, toplumsal, kültürel, siyasi, ekonomik ve teknolojik gelişmeler bu süreçlere yön vermiştir. Anadolu coğrafyası gibi farklı medeniyetleri birbirine bağlayan bir kesişim noktasında, söz konusu süreçleri etkileyecek çok farklı unsur bir araya gelmiş, bu kadim topraklarda sürekli bir dönüşüm ve değişim yaşanmıştır. Anadolu'nun sadece farklı kültürlerin buluşma noktası olması değil, aynı zamanda farklı fiziksel, iklimsel, coğrafi koşullara sahip olması insan yerleşimlerinin dokusunu, konut şemalarını, kullanılan yapım malzemelerini çeşitlendirmiştir. Bu çalışmanın amacı, Anadolu'daki çeşitliliğin mekânsal boyutunun irdelenmesi ve tarihsel gelişim süreci içinde Anadolu'daki yerleşimlerdeki ve konut tipolojilerindeki gelişim, değişim ve farklılıkların, etkileşim halinde olunan medeniyetlerle birlikte değerlendirilmesidir.

Anahtar Kelimeler: Anadolu yerleşimleri, konut tipolojisi, yapım malzemeleri, tarihsel süreç.

\section{An Evaluation on Settlements and Housing Typologies in Anatolia within Historical Evolution Process}

\begin{abstract}
From past to present, people have wanted to shape and change the world they live in. Although at the beginning of this approach there are needs such as survival, shelter, protection and reproduction, human actions have become one of the dominant elements in the shaping of the space, with the addition of desires such as dominating nature, producing, developing and gaining power in the later period. Anatolian geography is an intersection point connecting different civilizations, many different elements that will affect the said processes have come together here, and there has been a constant transformation and change in this ancient land. Anatolia is not only the meeting point of different cultures, but also has different physical, climatic and geographical conditions, which have diversified the pattern of human settlements, housing schemes, and construction materials used. The aim of this study is to examine the spatial dimension of the diversity in Anatolia and to evaluate the developments, changes and differences in the settlements and housing typologies in Anatolia within the historical development process together with the civilizations that interact.
\end{abstract}

Keywords: Anatolian settlements, housing typologies, construction materials, historical process.

\footnotetext{
${ }^{1}$ Çevre ve Şehircilik Bakanlığı,

* Illgili yazar/Corresponding author: cigdemtugac@gmail.com

Gönderim Tarihi / Received Date: 07.03.2021

Kabul Tarihi / Accepted Date: 24.04.2021
} 


\section{Giriş}

İnsanoğlu için barınma temel bir intiyaçtır. Günümüzde ulusal ve uluslararası belgelerde ve mevzuatlarda yerini almış bu intiyacın kökenlerinin çok eski çağlara kadar gittiği görülmektedir. Barınma ihtiyacının karşılanması doğrultusunda insanlar, Neolitik dönemden önce bitki ve hayvanlardan elde ettikleri malzemelerden yaptıkları geçici barınaklarda ve mağaralarda yaşadıktan sonra, Neolitik dönemle birlikte köyler ve evler inşa etmeye başlamıştır. İnsan yerleşimleri ve konutlar, insanların yaşam biçimleri, inanışları ve tarihsel süreçteki gelişimleri hakkında önemli ipuçları sağlayan kaynaklardır. Yerleşim yerlerinin ve bunlar içinde konut tipolojilerinin ${ }^{2}$ sosyal, kültürel, ekonomik özellikler ve çevresel, iklimsel, fiziksel faktörlerden etkilendiği ve bunlara ek olarak kullanım amacı-işlev unsurunun da söz konusu formlarda belirleyici olduğu görülmektedir (Bozkurt ve Altınçekiç, 2013, s. 70; Salihoğlu, 2001, s. 10). Özellikle Anadolu'daki yerleşimler bu kapsamda tarihsel gelişim süreci içinde önemli bir çeşitliliğin ortaya çıkmasını sağlamış durumdadır.

Bu doğrultuda çalışmanın amacı, Anadolu'daki söz konusu çeşitliliğin mekânsal boyutunun irdelenmesi ve tarihsel gelişim süreci içinde Anadolu'daki yerleşimlerdeki ve konut tipolojilerindeki gelişim, değişim ve farklılıkların, etkileşim halinde olunan medeniyetlerle birlikte değerlendirilmesidir. Çalışma bu kapsamda yerleşim ve konut özelliklerinin dönemsel bağlamda irdelendiği dört bölüm halinde ele alınmıştır: (1) Öncelikle, insanlığın tarım devrimini gerçekleştirerek yerleşik hayata geçtiği Neolitik Dönem ile Roma İmparatorluğu'nun yıkılışı arasındaki dönem incelenmiştir. (2) Ardından, Anadolu'da Bizans ve Selçuklu Dönemi ele alınmıştır. (3) Takip eden bölümde Osmanlı Dönemi incelenmiştir (4) Son bölümde ise, Cumhuriyetin ilanından günümüze kadarki dönem ele alınmıştır. Sonuç bölümünde, tüm bu bölümler kapsamında elde edilen bulgular doğrultusunda genel bir değerlendirme yapılmıştır.

\section{Dönemsel Bölümler}

\section{Anadolu'da Neolitik Dönem İle Roma İmparatorluğu'nun Yıkılışı Arasındaki Dönem}

Neolitik (Cilalı Taş) dönem öncesindeki Paleolitik (Yontma Taş) dönemde (yaklaşık MÖ 2.000.000-10.000 arası), sürekli bir gezginlik söz konusudur. Tarihçi Lewis Mumford, Paleolitik dönemi avcı-toplayıcılığın olduğu ve kalıcı bir yerleşime sahip olunmayan, "huzursuz bir göçebeliğin" hâkim olduğu dönem olarak nitelendirmektedir (Mumford, 2017, s. 17). Bu dönemde insanlar barınak olarak avlamış oldukları mamut gibi iri kemikli hayvanların adeta yapay bir gövde oluşturan kalıntılarından yararlanarak, kendilerine geçici çadır barınaklar, kamplar yapmışlardır. Soğuk iklim kuşaklarında durum böyleyken, ılıman iklimlerde, bu barınaklar ağaçların dal ve yaprak kısımlarından oluşturulmuştur. Ancak sonuç olarak her iki barınak tipinin de kullanılan doğal malzemelerin yapısı nedeniyle yuvarlak formlar oluşturduklarını söylemek mümkündür (Salihoğlu, 2001, s. 6, 7). Paleolitik dönemde insanlar mağaralarda sürekli olarak kalmamaktadır. Üreme ve gıda bulma amacıyla zaman zaman mağaralara gelmektedirler. Ancak mağaralar, erken evrede insanlarda ilk defa mimari mekân kavramını oluşturmaları bakımından önemlidirler (Mumford, 2017, s. 19, 20).

\footnotetext{
2 Tipoloji kavramı ile yapısal, biçimsel, işlevsel, yapı/çevre ilişkileri bağlamında yapı tipi tarif edilmektedir (Yenel, 2012, s. 9).
} 
Neolitik dönem (MÖ 10.000-5.500 yılları arası) ise insanlık tarihi için devrim niteliğinde bir gelişmeyi beraberinde getirir ve yerleşikliğe adım atılan ilk dönem olmuştur. Şüphesiz bu değişim birdenbire gerçekleşmemiş, avcı-toplayıcılık ve yerleşikliğin bir arada olduğu bir geçiş süreci de yaşanmıştır (URL 1). Yerleşiklik iki boyutta gerçekleşir. Mekânda var olmayı sağlayan bir nokta ve zamanda var olmayı sağlayan bir birikim. Günümüzde Güneydoğu Anadolu Bölgesi'nde Göbeklitepe gibi kutsal merkezlerde yapılan arkeolojik kazılar, Neolitik dönem insanını belli bir noktada yapı inşa etmeye teşvik eden önemli bir unsurun yukarıda ifade edilen birikim doğrultusunda önceki dönemlere kıyasla daha karmaşık inanç sistemlerine sahip olmalarıyla ilişkilendirilmektedir ve ilk kamusal yapılar olarak ele alınabilecek tapınaklar da bu dönemde inşa edilmiştir (Özdöl, 2011, s. 190; URL 2).

Bir milyon yıldan fazla süren göçebe yaşamından sonra, Neolitik dönemde köylerin oluşması ile sabit bir yerleşim yerinde yaşanmaya başlanması, insanlığın gelişiminde önemli bir aşamadır çünkü sürekli hareket halindeki küçük grupların beslenme, korunma ve küçük çocukların bakımı gibi konularda karşılaştıkları güçlükler, yerleşikliğe geçişle olumlu yönde değişmiştir. Köylerde tarımsal üretimin başlaması ve hayvanların evcilleştirilmesi ile ilerleyen süreçte kentlerin oluşmasına temel oluşturacak olan insan sayısındaki ve gıda üretimindeki artış da mümkün olmuş ve bu dönemden kentlere aktarılacak olan temel unsurlar da üretilmeye başlanmıştır (Mumford, 2017, s. 24, 29; Solmaz, 2019, s. 869). Neolitik dönem, Çanak Çömlekli Neolitik Dönem ve Çanak Çömleksiz Neolitik Dönem olarak ikiye ayrılmaktadır. Neolitik dönemde her bina, hem konut hem de depodur. Depo da konut da yuvarlak formun kolaylığında ve yalınlığında biçimini bulmaktadır (Öztürk ve Şimşek, 2019, s. 19). Bu formun ve dönemin Anadolu'daki en belirgin örnekleri Diyarbakır'daki Çayönü yerleşmesinde görülebilmektedir. İlk kez Çayönü yerleşmesinde alt bölümleri taştan, üstleri kerpiçten, konik örtülü, yuvarlak çukur yapılar yapılmıştır ve bu yapılar aşamalar halinde değişerek yerini dikdörtgene ve oradan da ayrı duvarları ile düz damı olan yapılara (Şekil 1) bırakmıştır (Özdemir, 2017, s. 255; URL 1).
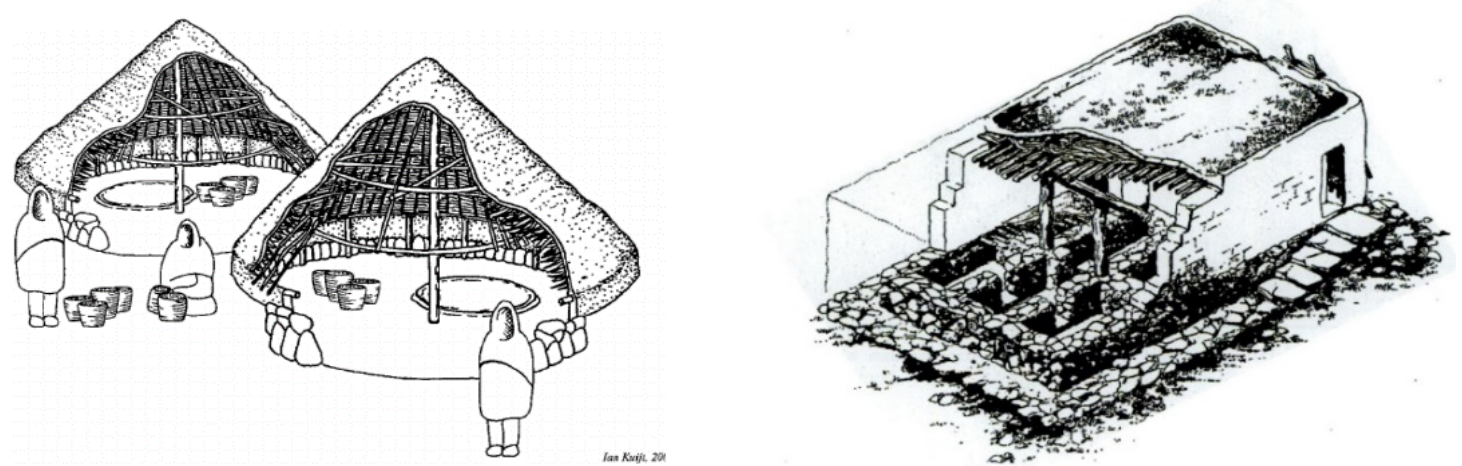

Şekil 1. Çanak Çömleksiz Neolitik Dönem, Çayönü yerleşmesinde konut biçiminin değişimi (Kavas, 2020, s. 536; URL 2)

Yerleşim özellikleri ve yapı malzemeleri bağlamında dikkati çeken ve farklılık arz eden ve bir kısmı Anadolu topraklarında kaldığı için bu çalışma kapsamında ele alınan bir diğer yerleşim yeri de Mezopotamya'dır. Yukarıda ifade edilen ilk kalıcı yerleşmeler bu bölgeye komşu topraklarda ortaya çıksa da insanlık tarihindeki bu önemli gelişmelerin sonuçları, arkeolog Gordon Childe tarafından 'şehir devrimi' olarak nitelendirilen olguyu ortaya çıkarmış, ilk kent yerleşimleri Dicle ile Fırat arasındaki günümüzde Güneydoğu Anadolu, Irak, Kuzeydoğu Suriye ve Güneybatı İran topraklarından oluşan bölge yani 
Mezopotamya'da ${ }^{3}$ ortaya çıkmıştır. Bu nedenle Mezopotamya, medeniyetin beşiği olarak kabul edilmektedir. MÖ 5000 ve 7000 'lerde toplumsal, ekonomik ve kültürel gelişme bu bölgeye kaymıştır ve Mezopotamya çok sayıda medeniyete ev sahipliği yapmıştır (Childe, 2009, Eisner vd., 1963, s. 53; Özdöl, 2011, s. 173; Tekin, 2017, s. 17).

Mezopotamya'da taş materyal çok fazla değildir. Evler kerpiçten yapılmıştır ve iç avlulu bir yapı göstermiştir. Kentleşme topografya düz olduğu için düz ve gridaldir. Ancak her halükârda bina zemini için taşa intiyaç vardır. Çünkü bölgenin bol yağış alması nedeniyle zemin ıslaktır. Ancak Mezopotamya'nın verimli tarım arazilerinden yılda birkaç kez hasat yapma olanağı söz konusu olmuştur. Taş intiyacı doğrultusunda en yakın yerlerden biri olan İran'dan taş alınıp, ürün ile takas edilmiş ve bunun gibi diğer çevre yerleşmelerle de farklı alanlarda ticareti geliştirmişlerdir. Taş az ve değerli olduğundan yalnızca temelde kullanılmış, üst kısımlar ise kerpiçten yapılmıştır. Ama bu dayanıklı bir malzeme değildir, dayanıklı hale gelmesi için pişirilmiş ve tuğla ortaya çıkmıştır. Dayanıklılığının daha da artması için tuğlayı sırla ${ }^{4}$ kaplamışlardır. Kentleri savunma amaçlı olarak tuğladan surlarla çevrelemişler ve çevresini de hendek ve kanallarla destekleyerek savunmayı kolaylaştırmışlardır. Bu hususlara Gılgamış Destanı'nda Mezopotamya'daki Uruk kentine ilişkin betimlemelerde de yer verildiği görülmektedir: “Istihkamlarla korunan Uruk'a sur inşa etti,..Çıkın yürüyün Uruk'un surlarında. Taraçalarını gezin, tuğla işini inceleyin: Tuğla işi yakılmış tuğladan değil mi?" (Mumford, 2017, s. 88, 100).

Neolitik dönemde Anadolu'daki yerleşmeler kapsamında ele alınması gereken bir diğer önemli yerleşme ise Orta Anadolu'da Konya Ovası'nda yer alan, Çanak Çömlekli Neolitik Çağ yerleşmelerinden MÖ 7.020-6.500 yılları arasına tarihlendirilen Çatalhöyük'tür (Ünsal, 2020, s. 325). UNESCO Dünya Mirası Listesi'nde yer alan yerleşme düz bir alanda kurulmuştur. Yapılar birbirine bitişik olarak yapılmıştır ve girişleri çatıdandır. Yapılar arasında ev, tapınak ayrımı yoktur. Yapım malzemesi olarak pişmemiş kerpiç bloklar kullanılmıştır. Tarihte bilinen ilk kent planı, Çatalhöyük'te bir evin duvarında resmedilmiştir ve kent genelinin yine kerpiç malzemenin etkisiyle gridal (ızgara) yapıda şekillendiği (Şekil 2) anlaşılmaktadır (URL 3; URL 4).
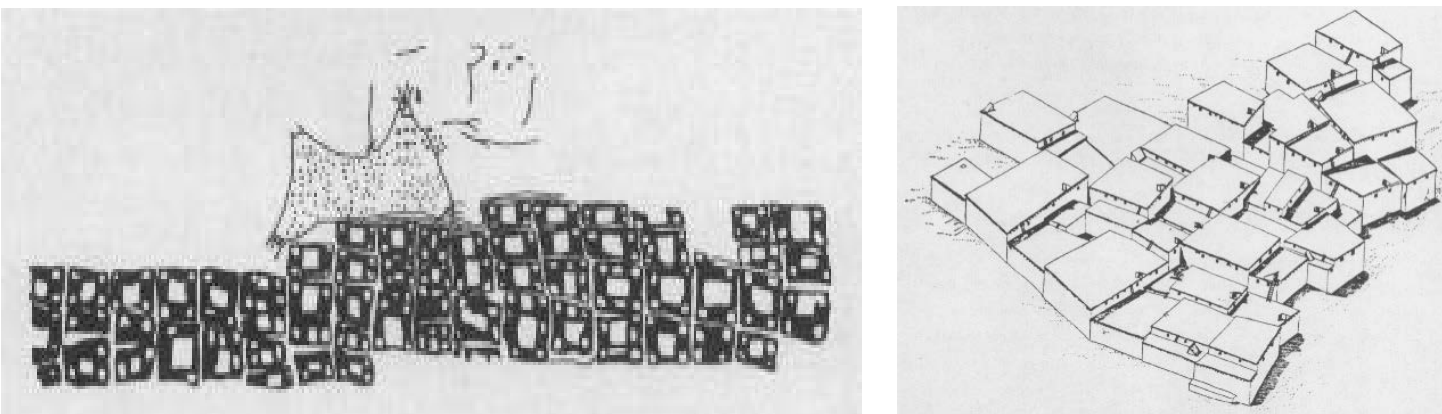

Şekil 2. Çatalhöyük Şehir Planı ve evlerin olası dıştan görünümü (Akurgal, 1990, s. 23, 24)

Neolitik dönemi takip eden Kalkolitik dönemde Anadolu ikliminin normalleşmesi ve günümüzdekine benzer coğrafi koşulların oluşması dolayısıyla nüfus artışı olmuştur. M.Ö. 5.000'in sonlarına doğru madencilik daha da gelişmiş ve bakır ve kalay gibi madenler işlenmeye başlanmıştır. Geç Kalkolitik dönemde özellikle Güneydoğu ve Doğu Anadolu'da kentlerde kamu binaları ve dinsel yapılar görülmektedir. Bu dönemin

\footnotetext{
${ }^{3}$ Mezopotamya iki nehir arası demektir ve burada kastedilen iki nehir de Fırat ve Dicle nehirleridir.

4 Pişmiş toprak eşya ve yapı malzemesi üzerine sürülerek fırınlanan ve bunların üzerini saydam bir katmanla örterek su ve benzeri sıvılardan etkilenmemesini sağlayan koruyucu malzeme (Sözen ve Tanyeli, 2014, s. 275)
} 
önemli temsilcilerinden biri Malatya-Arslantepe Höyüğü'dür. Neolitik dönemden Kalkolitik döneme geçişte ve ilk Tunç dönemindeki yerleşme ve yapılaşma tipolojilerinde Güneydoğu Anadolu ve Doğu Anadolu'daki kentlerde söz konusu gelişmeler ortaya çıkarken, Orta Anadolu'daki yerleşmelerde çok büyük farklılıkların olmaması, Güneydoğu Anadolu ve Doğu Anadolu'daki kentlerin Mezopotamya ile etkileşim halinde olmasıyla açıklanmaktadır (URL 1; Arslan, 2016, s. 1)

Illk Tunç Çağına gelindiğinde Anadolu'daki yerleşmelerde metal zenginliği ve özellikle Mezopotamya ile artan ticari faaliyetler ön plana çıkmıştır. Bu dönemde Anadolu'da megaron tipi evler yaygınlaşmıştır. Megaron, kare veya dikdörtgen planlı, girişi önden olan, tek odalı, ortasında ocak yer alan, önceleri kerpiçten daha sonra taştan yapılan birim konut tipidir (Akurgal, 1990, s. 27; Bozkurt ve Altınçekiç, 2013, s. 72). Bu durum, bulunulan bölge ile malzeme, malzeme ile form arasındaki ilişkiyi de ortaya koymaktadır. Ancak malzeme çeşitliliği artsa da genel kent formu değişmemiştir ve ızgara şemadır. Ancak topoğrafyaya bağı olarak bazen şema deforme olabilmiştir (Özcan, 2007, s. 296).

Anadolu'nun tarihsel gelişimi içinde Hitit ve Frig kentlerinden de bahsedilmelidir. Hititler'de (M.Ö. 1600-1200) yapı sanatının gelişmiş olduğu görülmektedir. Hititlerde yapı adaları bitişik düzendedir ancak her konut bir sokağa veya meydana açılmaktadır. Yapılarında sandık duvar tekniği ${ }^{5}$ ile kalın duvarlar yapmışlardır. Yapılar bir ya da iki katlıdır, genellikle bir avlunun etrafındadırlar ve pencereleri vardır. Yer döşemeleri taştır (Bozkurt ve Altınçekiç, 2013, s. 73; Salihoğlu, 2001, s 10; Atila, 2018, s. 181; Salihoğlu ve Demirarslan, 2018, s. 1775). Anadolu'da Demir Çağı'nda (M.Ö. 1200-330) özellikle İç Anadolu'da önemli bir konumda bulunan Frigler (M.Ö. 750-300) ise ahşap işçiliğinde ileri gitmişler, materyal olarak taşı da kullanmışlardır. Gordion kentinde kerpiç duvarlı, taş temelli surlar da bulunmaktadır ve içerisinde yer alan konutlar dörtgen planlıdır. Frig konutlarının temelleri taş, üst kısımları ise bazen taş, bazen de ahşap hatıllarla güçlendirilmiş kerpiç yapılardır ve megaron plan uygulanmıştır (Arslan, 2016, s. 5, 8; Bozkurt ve Altınçekiç, 2013, s. 74).

Antik döneme gelindiğinde Batı Anadolu'da çok sayıda koloni kentleri kurulmuştur. Arkeolog Ekrem Akurgal bu dönemde İon medeniyeti tarafından kurulan koloni kentleri ile Batı Anadolu'nun dünya kültür liderliğini uzun süredir elinde tutan Mısırlılardan ve Mezopotamyalılardan aldığını ve dünyanın en ileri bölgesi haline geldiğini belirtmiştir (Akurgal, 1990, s. 203). Ticari faaliyetler önemlidir. Kent yani polis, bugünkü anlamda devlet demektir. Kentlerde tam bir mekânsal ve işlevsel uzmanlaşma vardır. Çoğunlukla liman kentleri gridal form gösterirken, Anadolu'nun iç kısımlarında tarım alanlarını korumak, güneşlenme ve havalandırma olanaklarından yararlanmak için konutların güneye bakan yamaçlarda yapıldığı görülmektedir (Catanese ve Snyder, 1988, s. 7). Anadolu'da Antik Çağ'da planlı bir biçimde ızgara plan olarak tasarlanan kentlere en iyi örnek Hippodamus'un tasarladığı Miletos'tur (Şekil 3). Artık yerleşmelerde oval forma rastlanmamaktadır (Abbasoğlu, 1996, s. 66; Özcan, 2007, s. 296). Kent meydanı agora, ticaret merkezi ve pazar yeridir. Toplanma mekânı tiyatro, kentte dominant bir elemandır. İklim ve peyzaj yönünden limanlar kentin içine dek sokulmaktadırlar (Gözlü, 2015, s. 180; Günay, 2012, s. 139; Mumford, 2017, s. 173; Tekkanat ve Türkmen, 2018, s. 112).

\footnotetext{
${ }^{5}$ Sandık duvar tekniğinde; önce taştan duvarlar örülmekte ardından odacık gibi boşluklar bırakılarak, odacıklar taştoprak ile doldurulup üstü kapatılmaktadır. Böylece 10 metre kalınlığında duvarlar yapılabilmiştir (Bozkurt ve Altınçekiç, 2013, s. 73).
} 


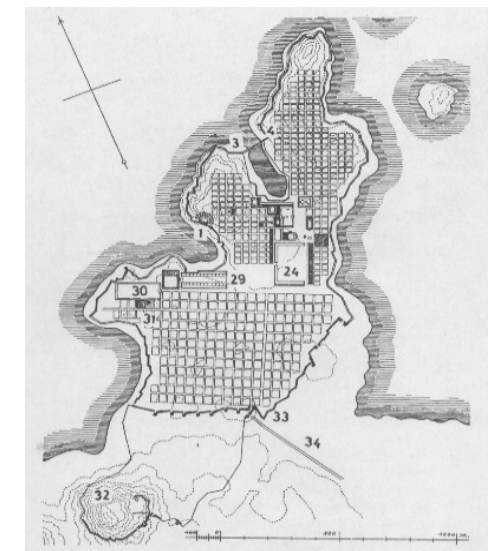

Şekil 3. Miletos Kenti Planı (Akurgal, 1990, s. 446)

M.Ö. 735'te kurulan Roma İmparatorluğu'nun kentlerinde sanat ve yapı hep politika içindir. Etrüsk ve Helen kültüründen etkilenme söz konusu olmuştur. Mekânda fonksiyona önem verildiği görülmektedir. M.Ö. 30'dan itibaren Roma'nın egemenliğine giren Anadolu'da, Efes ve Perge kentlerinde yer alan konut alanlarında dikdörtgen planlı, ızgara şemaya oturan yerleşim deseninin söz konusu olduğu görülmektedir. Tipik bir Roma yerleşiminin gösterimi için Timgad iyi bir örnektir (Şekil 4). Timgad, Anadolu'da değildir ancak, Roma kentlerinde uygulanan bu şema tüm kentleri için standart niteliğindedir. Bu standart kent şemasının kentin savunma kolaylığı, toplumsal hiyerarşik yapı ve malzeme kullanımı gibi nedenlerle uygulandığı anlaşılmaktadır. Bu tip Roma kentlerine 'Castrium Romanum-Roma Karargâhı' denilmektedir (Mumford, 2017, s. 254, 256). Evler çoğunlukla iç avlulu domus adı verilen konutlardır ancak bunların yanı sıra Roma Dönemi'nde insula adı verilen çok katlı ilk toplu konut örneklerinin de geliştirildiği görülmektedir. Zengin aileler ise kentlerin dışındaki villa tipi konutlarda yaşamışlardır (Gallion ve Eisner, 1963, 72; Ceylan, 2004, s. 1; Bozkurt ve Altınçekiç, 2013, s. 75; Karaca, 2020, s. 325).

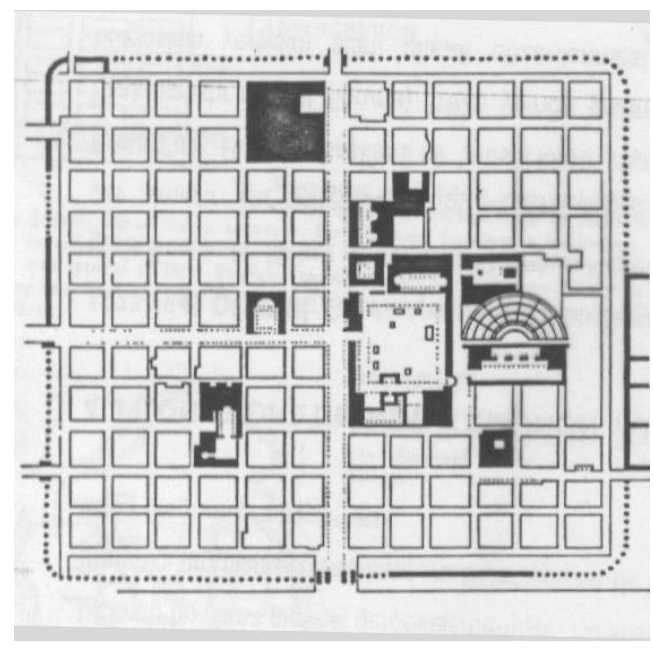

Şekil 4. Roma Döneminde Timgad Kenti (Gallion ve Eisner, 1963: 72)

Romalılar, yapı malzemesi olarak Roma betonu yani potzolona denilen bir karışım kullanmışlardır. Karışımın içinde volkanik kül, kireç ve su bulunmaktadır. Taşlar içten ve dıştan yerleştirilerek ikisinin arasına potzolonaya taş eklenip dökülerek kullanılmıştır (Abbasoğlu,1999, s.66). Roma kentlerinde yollar birbirini dik açı ile kesmektedir. Kuzeyden güneye uzanan yol cardo, doğudan batıya uzanan yol ise decumannus olarak adlandırılmıştır. Roma kentlerinde, kent meydanı agora, akropolis ile birleşerek 
yerini forum'a (senatonun önündeki kısım) bırakmıştır (Mumford, 2017, s. 256). Roma İmparatorluğu M.Ö. 395'te ikiye ayrılmıştır. Batı Roma İmparatorluğu, Hun akınlarından etkilenerek yıkılmıştır, Doğu Roma İmparatorluğu yani Bizans ise devam etmiştir. Roma döneminde ön planda tutulan Izgara şema Bizans'ta uzun bir süre uygulanmayacaktır (Gallion ve Eisner, 1963, s. 73; Özcan, 2007, s. 296).

\section{Anadolu'da Bizans Dönemi ve Selçuklu Dönemi}

Roma İmparatorluğu dağıldığında Batı Avrupa'da kavimler arasında savaşlar olmaya başlamıştır. Kent nüfusları oldukça azalmış ve güven ortamı kaybolmuştur. Bu koşullarda ekonomik faaliyetler giderek daha fazla tarıma dayalı olarak gelişmiştir. Yönetim feodal beylerin eline geçmiş ve Orta Çağ başlamıştır. Orta Çağ kentleri biraz da bu güvensiz ortam nedeniyle, sur içinde kendi içine dönük kentlerdir. Roma İmparatorluğu'nda uygulanan gridal form artık bozulmuştur, topografyaya uyumlu organik yapı hâkim olmuştur. Anadolu kentlerinde ızgara planlı şema ancak 19. yüzyılda görülmek üzere terkedilmiştir (Keleş, 2013: 33; Mumford, 2013, s. 308; Özcan, 2007, s. 296).

Anadolu'da Bizans dönemi içerisinde yapı sanatı çok gelişmemiştir. Dini yapılara önem verilmiş, bunun dışındaki yapılarda örneğin, kırsal alandaki konut yapılarında ön direkli kerpiç yapılara ve köy düzenine geri dönülmüştür. Yani Orta Çağ'ın Anadolu yüzünde evler küçüktür ve gelişmemiştir. Zaten Bizans ile en çok özdeşleşebilen kent de başkenti Konstantinopolis/İstanbul olmuştur. İstanbul'da yaşayan varlıklı tabakanın lüks evleri dışındaki konutlar gecekonduyu andıran, çatıları hasır ile kaplı, toprak tabanlı konutlardır. Bizans döneminde antik kentlerin görkemini yansıtan hipodrom, tapınak ve tiyatro gibi yapıların terk edildiği görülmektedir. Anadolu'da Bizans kentleri büyük köylere dönüşmüştür. Kerpiçten iki katlı evler, düz damlıdır ve bir avlu etrafında yer almışlardır. Kırsal alanda Geç Bizans Dönemi'nde ayrıca Nevşehir ve Göreme'de mağara yerleşme alanları da görülmektedir (Koçyiğit, 2013, s. 13; İşler, s. 291, Tunay, 1997, s. 100; Uysal, 2013, s. 11).

Yukarıda da değinildiği gibi ızgara şema terkedilmiş olmakla birlikte Türklerin Anadolu'ya gelişlerinin ardından başlayan Beylikler Dönemi'nde ve Bizans İmparatorluğu'nun hüküm sürdüğü dönem boyunca çok nadir de olsa Ege kıyılarında yer alan Scalanova (Kuşadası), Nea Focia (Yeni Foça) gibi koloni kentlerinde ızgara şemanın görüldüğü belirtilmelidir (Özcan, 2007, s. 296).

Türkler, Orta Asya'dan Anadolu'ya 11. yüzyıl itibariyle siyasi karışıklıklar ve iklim şartları gibi nedenlerle göç etmeye başlamış, 1071 yılında Malazgirt Savaşının kazanılmasından sonra göçler yoğunluk kazanarak devam etmiştir. Türklerin Anadolu'ya gelmeden önce de yerleşik yaşamı benimsedikleri görülmektedir. Orta Asya'da at yetiştirdiklerinden, büyük at sürülerinin ardından yer değiştirmeleri gerekmiştir ve belli göç güzergahları vardır. Yapacakları yaylak ve kışlaklar için oba yani çadırları barınak olarak kullanmışlardır (Sözen ve Eruzun, 1992, s. 20). Yerleşik yapılarında ise taş ve kerpiç malzeme kullanarak evler ve mahalleler oluşturdukları görülmektedir (Şekil 5). Dolayısıyla Türkler'in ihtiyaca göre göçer veya yarı-göçer bir yaşam biçimi sergiledikleri ifade edilebilir. Orta Asya'da Maveraünnehir ve Horasan'da yapılan kazı çalışmaları, Türklerin burada kare planlı, dört eyvanlı ${ }^{6}$, merkezi kubbeli ve geniş avlulu yapılar inşa ettiklerini göstermektedir. Bu plan şeması daha sonra Anadolu'da inşa edilen Türk evlerinde de kendini göstermiş ve Selçuklu ve Osmanlı mimarisini de etkilemiştir. Bu şemanın kökeni esasen göçebe kültüre dayanmaktadır.

\footnotetext{
${ }^{6}$ Eyvan, üç tarafı kapalı önü açık mekandır ve hayatın/sofanın odaların arasına uzandığı oturma alanlarıdır (URL 5).
} 
Göç sırasında kullandıkları çadırların yan yana oluşu ve ortalarındaki ortak alan, sonradan geleneksel Türk evinde kendisini odalar ve sofa biçiminde gösterecektir. Çadırın iç mekanının kurgusu ise Türk evi odasına yansıyacaktır ve karşılaştıııldığında önemli benzerlikler olduğu görülmektedir (Şekil 6). (Bozkurt ve Altınçekiç, 2013, s. 71, Deniz, 2007, s. 27; Göğebakan, 2015: 45; Kavas, 2012, s. 509, 510).

Anadolu'da erken dönemde yapılan cami, medrese, külliye gibi yapılar ve konutlarda yapı malzemesi olarak tuğla kullanıldığı, ardından taşın da kullanılmaya başlandığı ve taş süslemeciliğinin geliştiği görülmektedir. Ancak Selçuklu'nun hemen öncesi ve Selçuklu döneminde tuğla, mescit ve türbelerde tek başına kullanılmış, cami ve medreseler gibi büyük ölçekli yapılarda ise kısmi olarak yer almıştır. Medrese yapılarında tuğla kullanımı camilere benzer bir görünüş ortaya çıkarmıştır. Ancak ilerleyen süreçte tuğladan inşa edilen yapılar giderek azalmıştır. Taş giderek daha yaygın bir biçimde kullanılmıştır. Konya İlinde Beyşehir'deki Kubad Abad Sarayı (Şekil 7) ve Kayseri'deki Keykubadiye Sarayı (Şekil 8) dönem mimarisinin önde gelen örnekleridir ancak Selçuklulardan günümüze hiç konut ulaşmamıştır (Bakırer, 1981, s. 5; Bakırer, 2017, s. 204; Bozkurt ve Altınçekiç, 2013, s. 76).

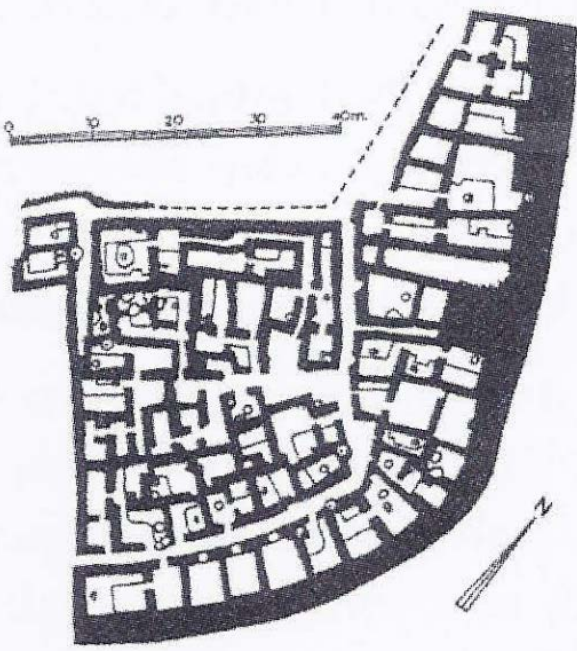

Şekil 5. Orta Asya'da (Kazakistan-Kuyrıktöbe) Sokak ve Konut Düzeni (Deniz, 2007, s. 28)
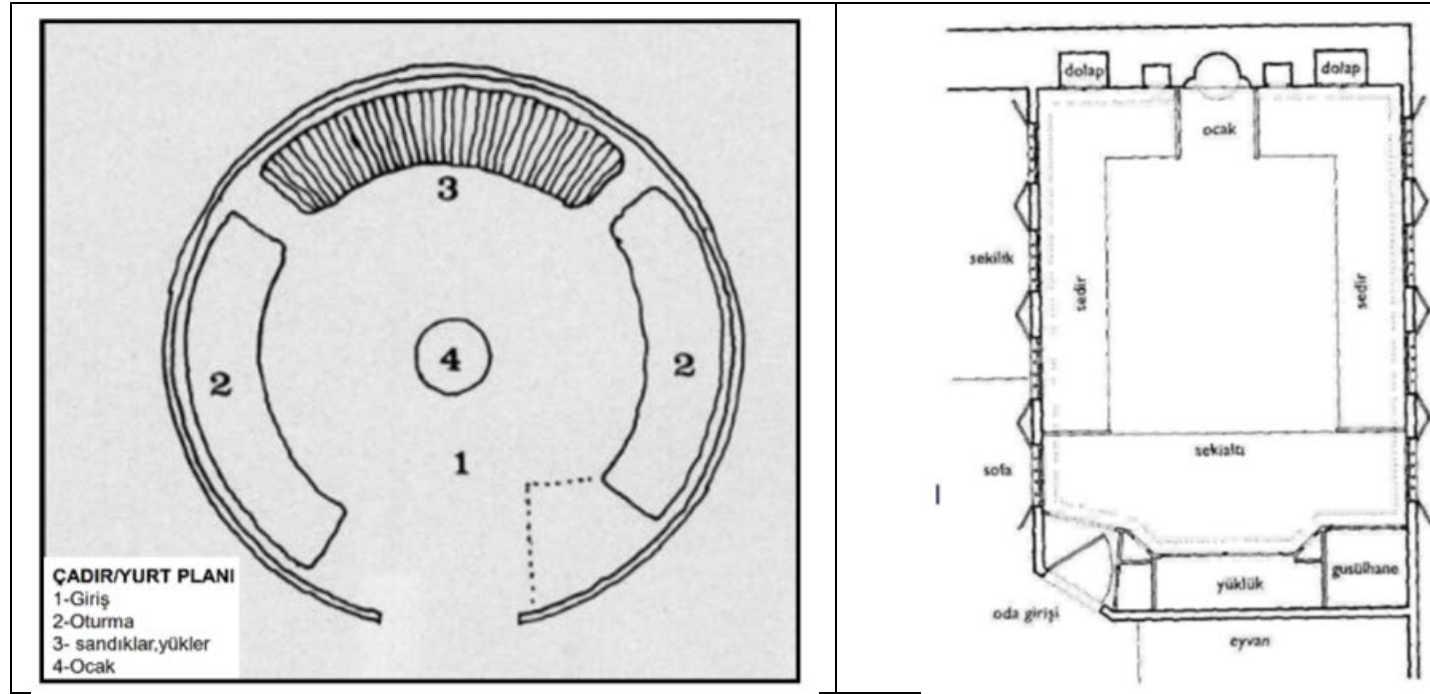

Şekil 6. Oba (Çadır) ve Geleneksel Türk Evinde Birim Öğe Oda Planı Karşılaştırması (URL 5) 


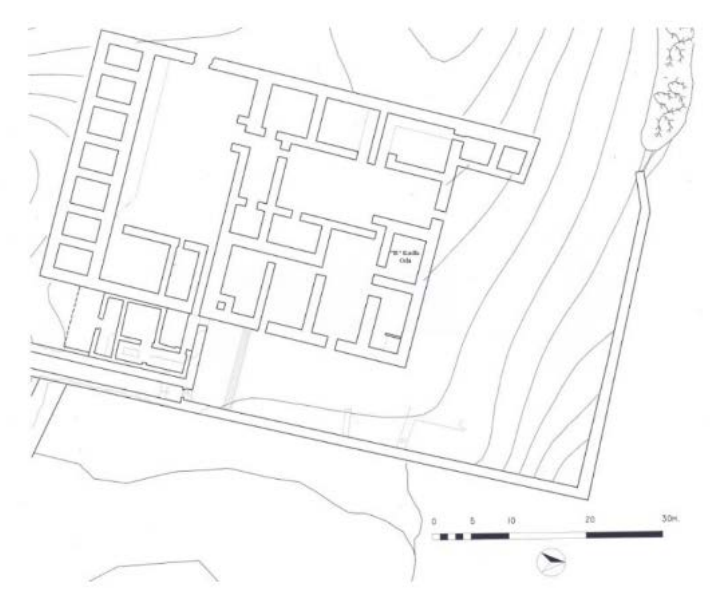

Şekil 7. Kubad Abad Sarayı (Acıoğlu, 2014, s. 3).
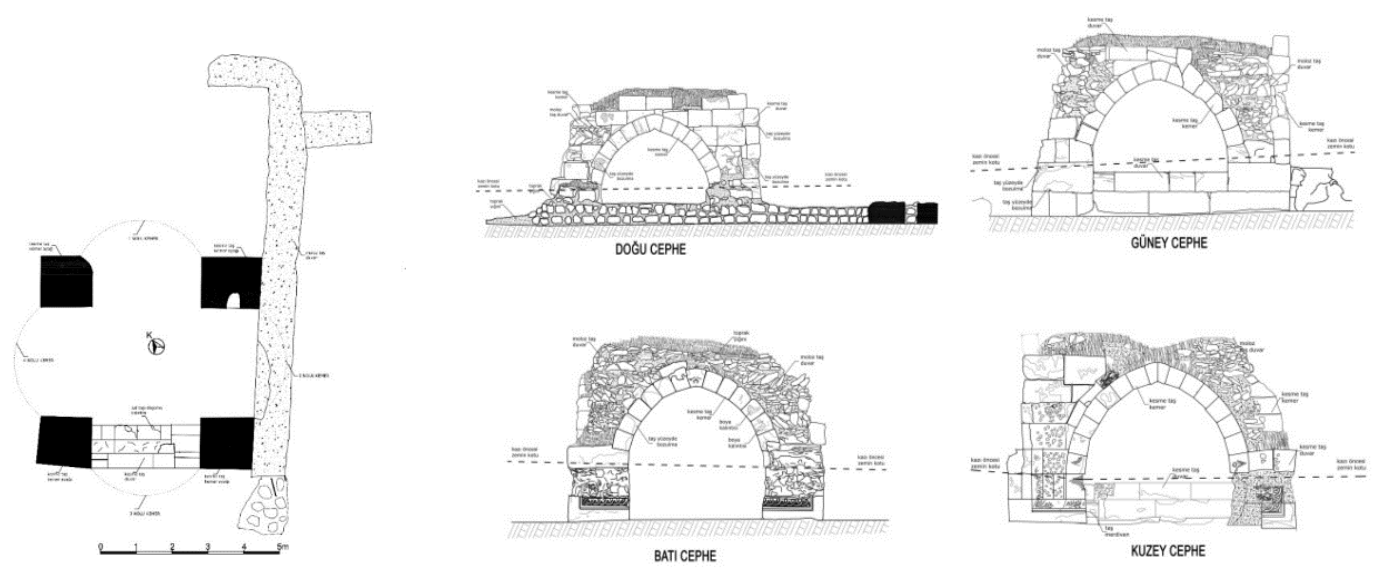

Şekil 8. Keykubadiye Sarayı-Dört Kemerli Yapı Cepheleri (Baş ve Dursun, 2017, s.104)

Anadolu Selçuklu Devleti döneminde kurulan kentlere bakıldığında kendine has bir doku oluşturduğu ve yeni kentler kurmak yerine mevcut kent yapılarını yıkmadıkları görülmektedir. Halihazırdaki Bizans kentlerine eklemlenerek ve mevcut yapılara yeni fonksiyonlar vererek kullanmışlardır. Kentlerdeki kiliselerin camiye çevrilmesi, manastırların tekke ve zaviye olarak kullanılması buna örnektir. Yani Türkler eski kente yerleşerek orayı geliştirmişlerdir. Türklerin Anadolu'ya gelmesinden önce sur içinde bulunan kale-kentler söz konusudur. Türkler pek çok yeni kale inşa etmişler veya eski kaleleri onarmışlardır. Aileleri ile birlikte burada kalarak kale-kent olgusunu güçlendirmişlerdir. Anadolu'da 13. yüzyılın ilk yarısında önemli kentler askeri amaçla kullanılan iç kale, onu çevreleyen konut alanları ve en dışta yer alan kalın surlarla çevrili dış kaleden oluşan bir görünümdedirler (Şekil 9). 13. yüzyılda ayrıca Anadolu'daki kentlerin gelişiminde etkili olan unsur ticaret olmuş, kervan ticareti nedeniyle yeni merkezler kurulmuştur. Ticaretin gelişmesinin etkisi ile dış kale ortadan kalkmaya başlamış ve kentlerde sadece iç kale yer almıştır (Kejanlı, 2010, s. 290; Ökmen ve Yılmaz, 2009, s. 93). Anadolu Selçuklu Devleti çeşitli sebeplerle yıkıldıktan sonra Anadolu'da Beylikler Dönemi yaşanmış ve bu beyliklerden Osmanlı Beyliği güçlenerek, Osmanlı Devleti kurulmuştur. 


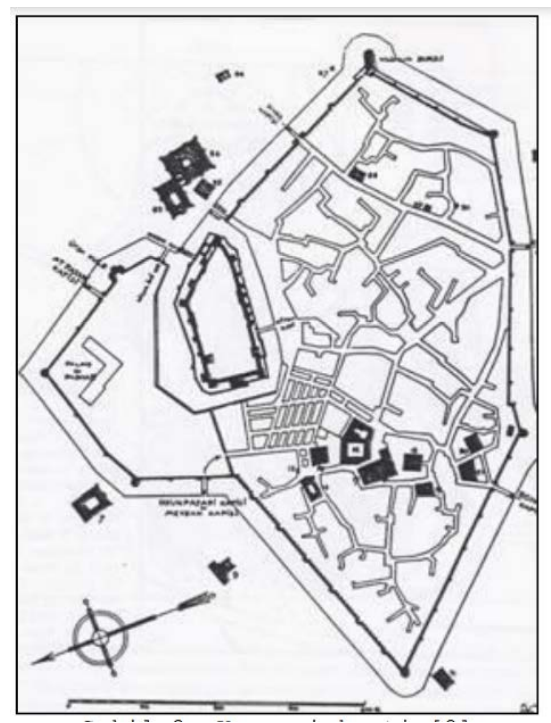

Şekil 9. 13. Yüzyıil-Kayseri kenti (Kejanilı, 2010, s. 291)

\section{Anadolu'da Osmanlı Dönemi}

Osmanlı kentlerini ve konut dokusunu ele alırken üç döneme ayırarak değerlendirme yapılabilir; (1) Erken dönem, (2) Geleneksel/Klasik dönem, (3) Batılılaşma dönemi. 13. yüzyıldan itibaren beylik iken giderek güçlenerek devlet haline gelen Osmanlı'da erken dönemden itibaren kentleşmeye önem verilmiştir. Osmanlı yerleşme sisteminin kuruluş aşaması 14. yüzyıl sonundan 15. yüzyılın ikinci yarısına dek sürmüştür. Erken dönemde Osmanlı'da da Selçuklu Dönemi'ndeki gibi yine mevcut kentlerin çevresine yerleşilmiştir. Ancak bu Osmanlı'nın bu erken evrede dahi kendine özgü bir kent düzeni oluşturmadığı anlamına gelmemektedir. Bizans kenti çevresine kurulan yerleşimler zamanla büyüyerek bütünleşip, topografya ile uyumlu organik formlar ortaya koymuşlardır. Yerleşimde doğaya saygı temel alınmış, tarım faaliyeti, iklimlendirme ve manzara koşullarını gözeterek yapılar düzlüklerde değil, güneye bakan yamaçlarda (Şekil 10) yapılmışlardır. Çok stratejik konumdaki kentlerde var olan kaleler tamir edilmiş ve 15. yüzyılda Fatih Sultan Mehmed döneminden başlayarak Anadolu kıyılarında limanları korumak doğrultusunda yeni kaleler inşa edilmiştir. Ancak bu dönemde surlarla çevrili kent yapısına çok seyrek rastlanmaktadır (Aliağaoğlu ve Uğur, 2016, s. 208; Kejanlı, 2010, s.Ökmen ve Yılmaz, 2009, s. 91; Özcan, 2007, s. 298).

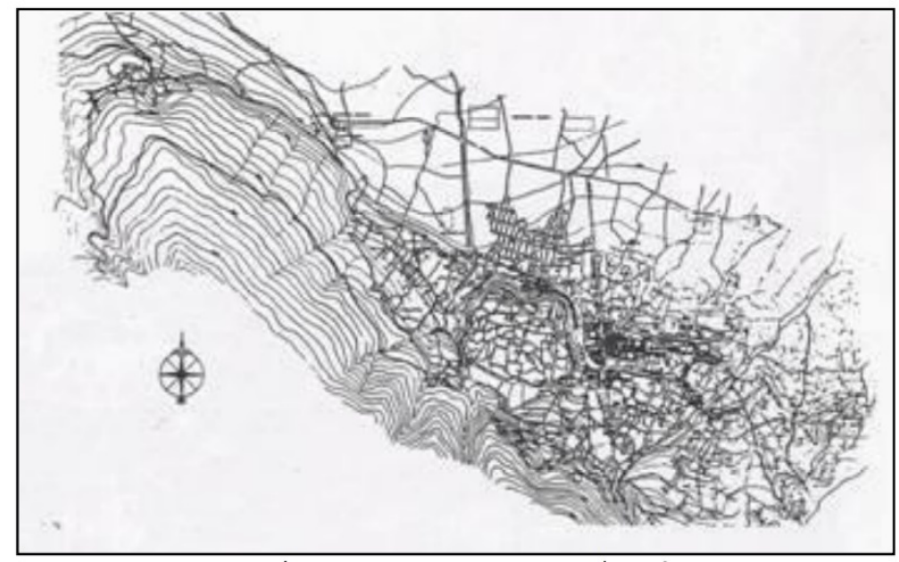

Şekil 10. Osmanlı kenti Bursa (Kejanlı, 2010, s. 295) 
Osmanlı'da Geleneksel/Klasik dönemin başlangıcı ile ilgili literatürde farklı yaklaşımlar ortaya konulmuştur. Bu dönemi, Erken dönemi de içine alarak 18. yüzyılın sonuna kadar süren bir dönem olarak değerlendiren yaklaşımlar olduğu gibi, Anadolu'da kentleşme hareketinin hızlandığı 16. yüzyıldan başlayarak ele alan ve yine 18. yüzyıl sonuna kadar sürdüğünü ifade eden yaklaşımlar da bulunmaktadır (Aliağaoğlu ve Uğur, 2016, s. 208; Ökmen ve Yılmaz, 2009, s. 91; Öz, 2005, s. 58) 17. yüzyılda Osmanlı, konargöçer halkı yerleşik düzene geçirmek doğrultusunda bir iskân politikası belirlemiştir. Dönem içinde baş gösteren Celali İsyanları dolayısıyla kırsal alanlarda yaşayan halk da kentlere göç etmişlerdir. Bu nedenle tampon bir bölge oluşturmak doğrultusunda Anadolu'da bazı kentlerin mahalleleri tek katlı surlarla çevrilebilmiş, bazıları surlarla korunmuş ve iç kaleleri de tahkim edilmiştir. Amasya, Ankara, İznik, Konya ve Bursa gibi kentler buna örnektir. Ancak bu dönemden 19. yüzyıla kadar, zamanla bir güven ortamının oluşması ve kale dışında yerleşmelerin yoğunlaşması ile surların işlevsiz kaldığı görülmüştür (Kejanlı, 2010, s. 295).

Osmanlı kentleri çok sayıda fonksiyonu içinde barındıran merkezi yerleşimler olarak nitelendirilmektedir. Osmanlı kentleri Roma kentlerinde olduğu gibi garnizon kentler olmamıştır. Çeşitlilik sadece fonksiyonlarda değil, etnik, dini, ekonomik ve sosyal yapıda da kendini göstermiştir. Bu dönemde Osmanlı kentlerinin ön plana çıkan ortak bazı özellikleri söz konusudur. Kentlerin yerleşim dokusu organiktir, arazinin doğal eğime göre kıvrılan sokaklar dardır ve bazen de çıkmaz sokak oluşumları görülmektedir. Kent merkezinde daha küçük ve bitişik olan yapılar, ortalarına kamu yapılarını almışlardır ve kentlerin dışına doğru gidildikçe parsel büyüklükleri artarak, bitişik nizam azalmaktadır. Sokağın iki yanı yüksek duvarlarla birbirinden ayrılmıştır. Duvarların üzerinde yer alan çıkmalar bu organik düzeni hareketlendirmiştir. Kentte sınıflara dayalı farklılıklar yoktur ve mahalle kültürü önemlidir. Evlerin yan yana gelişinde ana ilke komşunun perdelenmemesidir. Yapının biçimlenmesi, çıkma oranı, yapı yaklaşma miktarı gibi hususlar karşılıklı anlayış ve mimar denetimi ile belirlenmiştir. Osmanlı kentlerinin ticaret bölümleri yani çarşı, konut bölümlerinden ayrıdır ve kentlerin bir nevi merkezi iş alanına (MIA) sahip oldukları söylenebilir (Şekil 11). Çarşının yer seçiminde önemli yollar, kültürel alanlara göre konum, sur ve kale etkili olmuştur. Osmanlı kentlerinde ana yerleşim yerinden uzakta yer seçen yeni mahallelere 'şehre-küstü' denilmektedir. Şehre-küstü oluşumuna neden olan husus, kentin eski yerleşim alanının tamamen dolması ve yeni bir ev için yer kalmamasıdır. Bu nüveler zamanla yoğunlaşarak eski kentsel alanlara eklemlenmişlerdir (Aliağaoğlu ve Uğur, 2016, s. 203, 207, 214, 218; Gençel, 2000, s. 31; Göğebakan, 2015, s. 44; Kejanlı, 2010, s. 296; Ökmen ve Yılmaz, 2009, s.91; Özcan, 2007, s. 298).

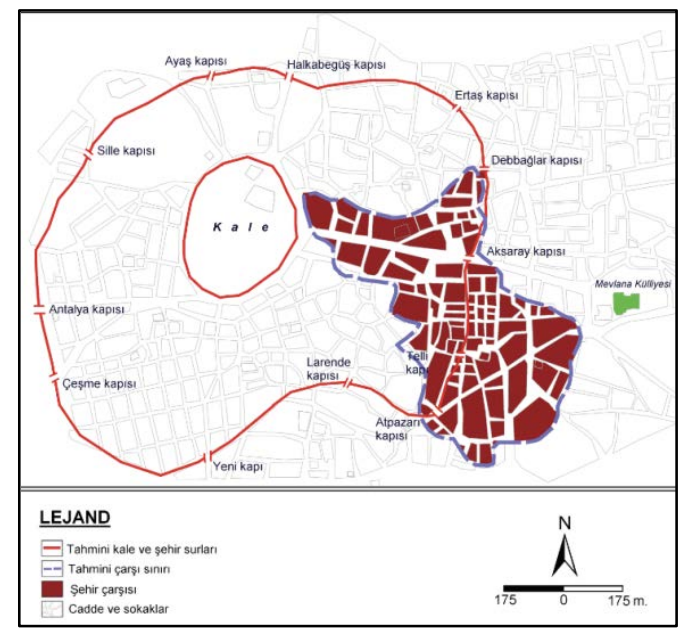

Şekil 11. Osmanlı kentlerinde çarşı ve organik şema-Konya (Şahinalp ve Günal, 2012, s. 149). 
Osmanlı dönemindeki geleneksel Türk evi, Sedad Hakkı Eldem tarafından "Türk evi, eski Osmanlı Devleti'nin işgal ettiği sınırlar içinde, eski tabiriyle Rumeli ve Anadolu mıntıkalarında yerleşmiş, inkişaf etmiş ve 500 sene kadar tutunmuş kendi vasıflarıyla tebarüz etmiş ev tipidir." şeklinde tanımlanmaktadır. Geleneksel Türk evi (Şekil 12) bahçeli, az katlı (en fazla üç katlı) yapı biçimine sahiptir. Osmanlı'nın farklı coğrafyalarda yayılışı sırasında geleneksel Türk evi biçiminin bu coğrafyalara da taşındığı ve özellikle Irak, Mısır ve Balkanlar'da etkili olduğu görülmektedir. Bunun tersi de doğrudur, yani geleneksel Türk evini şekillendiren ve köklerini Orta Asya'dan alan unsurlar sadece farklı coğrafyaları etkilememiş, Türklerin Anadolu başta olmak üzere hakimiyet kurdukları coğrafyalarda karşılaştıkları mimari unsurlar da geleneksel Türk evinde yerini bulmuş ve onu zenginleştirmiştir (Eldem, 1954, s. 10; Göğebakan, 2015, s. 44; Özcan, 2007, s. 298).

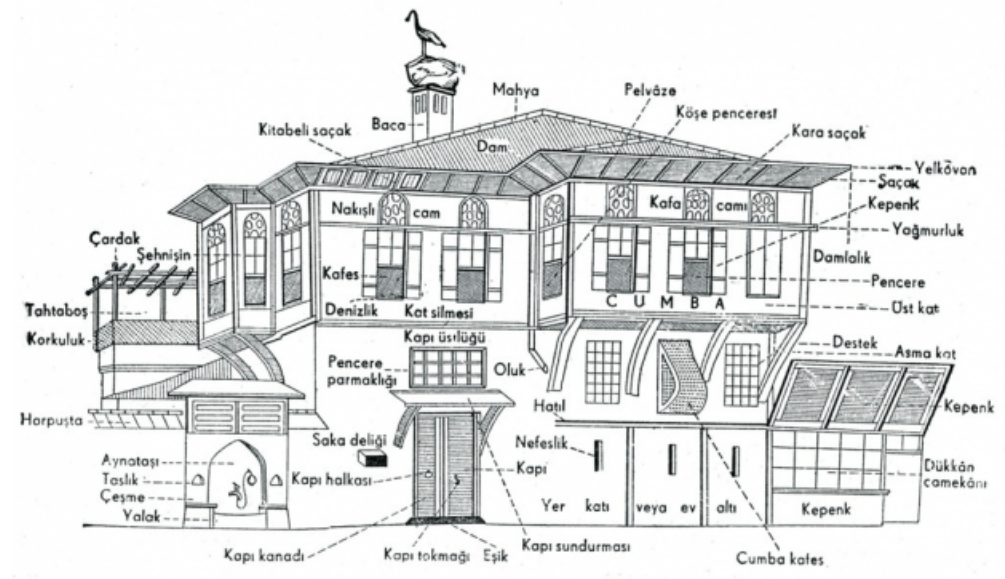

Şekil 12. Geleneksel Türk Evi (URL 6)

Geleneksel Türk evlerine ilişkin literatür incelendiğinde; plan tipine, sofa türüne, yapımında kullanılan malzemeye, konutun içinde bulunduğu coğrafi bölgeye ve yine konutun içinde bulunduğu iklim özelliklerine, konutun mimarisinin şekillenmesinde etkili olan medeniyetlere göre farklılaşan pek çok sınıflandırma olduğu görülmektedir.

Geleneksel Türk evinde, yapının yapıldığı bölgenin yerel malzemelerinin kullanılması önemli bir özelliktir. Anadolu yapılarında kullanılan malzemeler ahşap, taş ve kerpiçtir. Taş ve kerpiç yapılarda pencere gibi mimari elemanlarda ahşap kullanılmıştır. Ancak yapının tamamının ahşap yapılması planlanıyorsa temeli taştan yapılmıştır. Yapıda taşıyıcı olan ahşap kullanımı Doğu Karadeniz, Batı Karadeniz, Marmara, Trakya ve Rumeli, Ege ve Akdeniz bölgelerinde görülmüştür. Malzeme olarak ahşabın daha az olduğu yerlerde taş kullanılmıştır. Bu tip yerleşmelere örnek, Urfa ve Mardin evleridir. $\mathrm{Bu}$ sayede yöresel yapı tipolojileri farklılaşmıştır. Örneğin; malzeme olarak taş ve ahşabın az olduğu Orta Anadolu'da bu defa kerpiç, yaygın biçimde kullanılmış, ahşap hatıllarla desteklenmiş ve taş sadece binanın temel duvarlarında kullanılmıştır. Eğer yöresel malzeme bol ve çeşitli ise karma malzeme kullanımları da söz konusu olabilmiştir. Ancak malzeme olarak cam 17. yüzyılın sonuna kadar sadece sarayda kullanılmış, 18. yüzyıldan itibaren zengin ailelerin evlerinde de görülmeye başlanmıştır (Göğebakan, 2015: 48; Kuban, 1966, s. 15; Sözen ve Eruzun, 1992, s. 19, 20).

Doğan Kuban tarafından geleneksel Türk evlerine ilişkin sınıflandırma bölgesel özelliklere göre yapılmıştır. Buna göre (Kuban, 1982, s. 39):

1. Güneydoğu Anadolu'da taş mimari,

2. Kuzeydoğu Anadolu'da ahşap hatıllı taş mimari, 
3. Doğa Karadeniz'de ahşap mimari,

4. Ege ve Akdeniz Bölgelerinde taş mimari,

5. Orta Anadolu'nun Niğde ve Kayseri kesimlerinde taş mimari,

6. Orta Anadolu'nun köy ve küçük kentlerinde kerpiç mimarisi,

7. Anadolu'nun kıyıları, Diyarbakır'dan batıya ve İç Ege'den Torosların kuzey yamaçlarına kadar görülebilen hımış yapı tekniği kullanılan, taşıyıcı sistemi ahşap, kerpiç dolgulu, zemin katı çoğunlukla taş mimari olarak sınıflandırmıştır.

Sedad Hakkı Eldem tarafından geleneksel Türk evinde planı teşkil eden temel elemanlar (Eldem, 1954: 14):

1. Odalar

2. Sofalar ve müştemilat

3. Geçit ve merdivenler olarak tespit edilmiştir.

Geleneksel Türk evinde çok sayıda oda bulunmasının temel nedeni toplu yaşamaya ilişkin alışkanlık ve aile yapısı olmuştur. Kalabalık ailenin bir arada yaşadığı bu evlerde plan tipi değişse de yiyeceklerin saklanması ya da yeni evlenecek olan çocuğun oturması için ayrı bir oda mutlak suretle düşünülmüştür. Yani geleneksel Türk evinde birden fazla ailenin bir arada yaşadığı bir mekân kurgusu vardır. Sofa, her biri ayrı ev niteliğindeki odalar arasında yer alan, gerektiğinde tüm aile bireylerini bir araya getiren önemli bir mekandır (Şekil 13). Türk evlerinin plan şemalarının sofaya göre sınıflandırılması incelendiğinde (Şekil 14); sofasız plan, dış sofalı, iç sofalı, orta sofalı olarak değiştiği görülmektedir (Azezli, 2009, s. 10; Eldem, 1954, s. 18; Eruzun, 1987, s. 48; Göğebakan, 2015, s. 48-50).

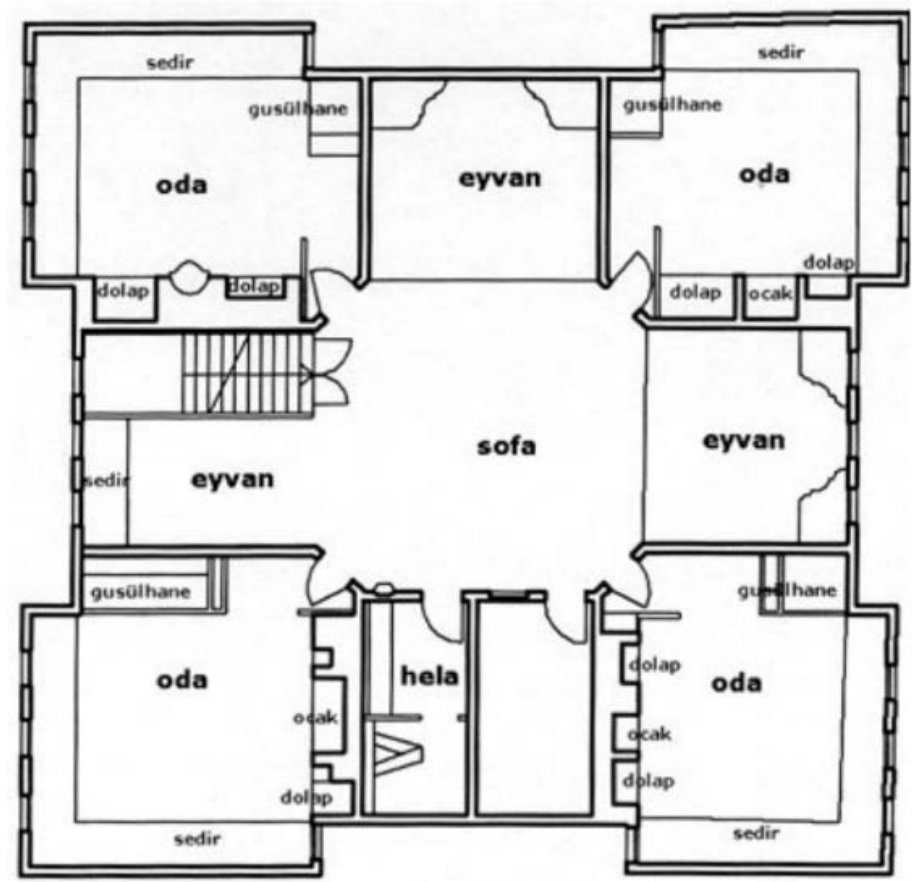

Şekil 13. Geleneksel Türk evinin öğeleri: eyvan, sofa, oda (Bayazıt, 2014, s. 3) 


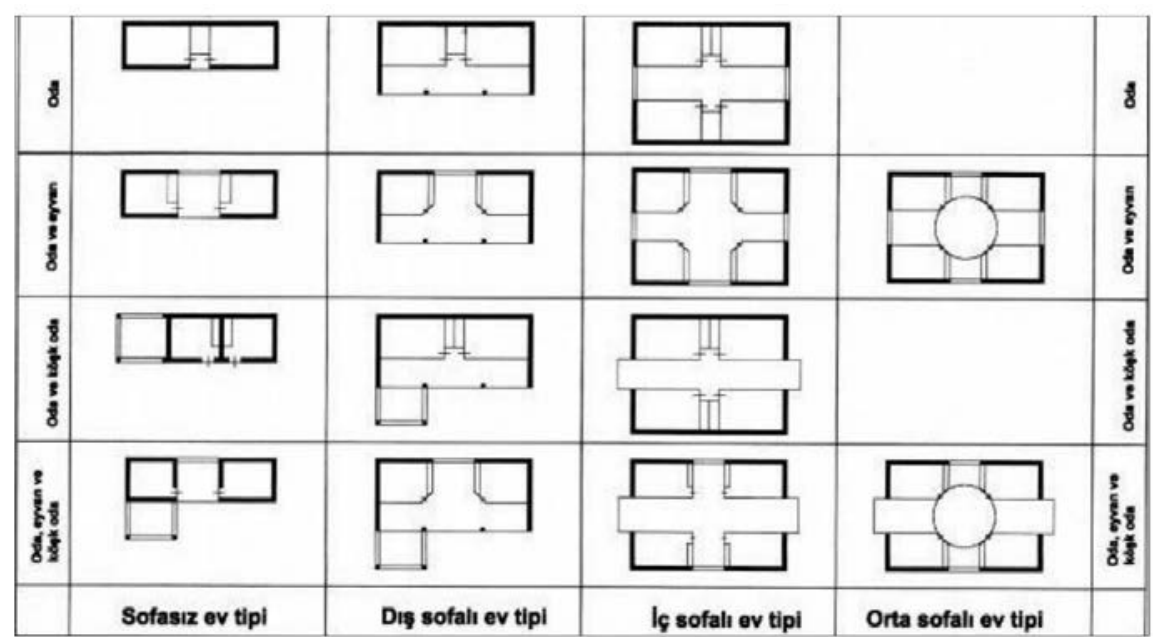

Şekil 14. Türk Evinin Plan Tipinin Sofaya Göre Sınıflandırılması (Yarış, 2020, s. 329)

Osmanlı kentlerinde 19. yüzyıldan itibaren önemli değişimler yaşanmaya başlanmıştır. Değişim hem fiziksel hem yönetsel boyutta hem de sosyal boyut bağlamında gerçekleşmiştir. Sınıf farkı olmayan mahalle yaklaşımı değişmiş, mahalleyi idare eden resmi kuruluşlar ortaya çıkmış ve dengeli toplumsal düzen ortadan kalkmıştır. Bu değişimlere öncülük eden 1839 'da Tanzimat Fermanı ile birlikte ele alınan reform hareketleridir. Bunun etkisiyle kentsel alan kullanımı bağlamında da önemli değişimler meydana gelmiş ve kentlerde ikili şema görülmeye başlanmıştır. Yani geleneksel organik şema ve bunun yanı sıra Osmanlı kentlerinde yeniden gündeme gelen ızgara şema. Izgara şemanın yeniden kentlerde görülmesinde demiryollarının gelişiminin yanı sıra, kent elitlerinin bu kent formunu yerleşmeye daha uygun bulması, yangın ve depremlerle geleneksel dokunun yok olması, toplumsal yapıda çekirdek aile sürecine geçişin başlaması etkili olmuştur (Aliağaoğlu ve Uğur, 2016, s. 218; Özcan, 2007, s. 297). 1839'da Tanzimat Fermanı ile başlayan ve I. ve II. Meşrutiyetle devam eden süreçte planlı kentleşme dönemi başlamıştır. Özellikle 1839 ile 1923 arasında çağdaşlaşma ile moderniteyi eş tutan dünya görüşü hâkim olmuş ve geleneksel plan kalıpları terk edilmeye başlanmıştır. Bu göreli modernleşme döneminde sıra evler ortaya çıkmış, bitişik bahçeli evler yapılmıştır. Bir diğer gelişme de apartmanlardır. 19. yüzyılın ikinci yarısında İstanbul'da Pera'da ve Galata'da başlayan apartmanlaşma ile çok katlı konut kültürü gelişmeye başlamıştır ve 20. yüzyıl boyunca Anadolu kentlerinde yaygınlaşmıştır (Bilgin, 1996, s. 294; Özcan, 2007, s. 297; Tekeli, 2001, s. 21).

\section{Cumhuriyetin İlanından Günümüze Kentsel Gelişim Ve Konut Tipolojisi}

\subsection{3-1950: Yavaş Kentleşme Dönemi}

1923 yılında Cumhuriyet ilan edilmiştir. Bu dönemden başlayarak 1950'lere kadar sürecek olan dönemde kentleşme yavaş gerçekleşmiştir. Bu dönemin başında başkent Ankara, tüm Anadolu kentleri için de bir prototip olarak düşünülmüştür. Plan anlayışında bulvar, cadde, kavşaklar ve gridal plan şeması ve radikal bir modernleşme söz konusudur. Bu durumun ortaya çıkmasında şüphesiz yabancı mimarların yerleşimleri planlanmaları etkili olmuştur. Batıda kullanılan yapı öğeleri doğrudan Türkiye'ye aktarılmıştır. Geleneksel yapı malzemeleri yerine yapılarda beton, çelik ve cam kullanılmıştır. Modernleşme süreci doğrultusunda haremlik selamlık anlayışın kalkması, kadının çalışma hayatına katılması, mutfaklarda ve misafir odalarındaki kullanım değişikleri gibi unsurlar, konut mekanına yansımıştır. Geleneksel geniş aile anlayışı yerini çekirdek aileye terk etmiştir (Bilgin, 1996, s. 294; Koca, 2015, s.19; Ülkü, 2018, s. 64, 69). 
Osmanlı'nın son dönemlerinde görülen ikili yapı Cumhuriyet'e de intikal etmiştir. Ayrıca II. Meşrutiyetin ilanı ile başlayan I. Ulusal Mimarlık Dönemi Cumhuriyetin kurulmasından sonra da devam ederek 1930'lara dek sürmüştür. Osmanlı'dan ve Selçuklu'dan devralınan ulusal özelliklerin ağır bastığı bu mimari dönem, eklektik bir yapı özelliği ortaya çıkarmıştır. Bu dönem eserlerine betonarme olarak inşa edilen II. Türkiye Büyük Millet Meclisi Binası ve Ziraat Bankası Binası örnek olarak verilebilir (Şekil 15). Bu dönemde çeşitli diğer akımların da ortaya çıktığı görülmektedir. Örneğin, Alman akımı ile apartmanlar oluşmuştur. 1939'dan 1950'lere kadar süren II. Ulusal Mimarlık Dönemi doğrultusunda geleneksel mimariyi örnek alarak yerel malzeme kullanımına dayalı ve iklim koşullarının göz önünde bulundurulduğu mimari çalışmalar gerçekleştirildiği de görülmektedir. 1930'ların sonu ve 1940'lı yıllarda devlet yavaş yavaş konut sektörüne girmiş ve devlet memurları için lojmanlar yapılmıştır (Şekil 16). Cumhuriyetin bu erken döneminde birçok Anadolu kentinde yeterli konut olmaması lojmanlar ile memurlara konut sunumu yapılmasını gündeme getirmiş ve lojmanlar planlı yapıları, sosyal tesisleri, ulaşım kolaylığı sağlaması ve güvenli bir ortamı sunması bağlamında olumlu özellikler içermişler ve iyi örnekler ortaya konulabilmiştir. Bu dönemde ayrıca mahalleler planla toplu konuta dönüşmüşlerdir. 1945'te kooperatifler için konut kredilerinin verilmesi konut üretim biçimlerinin değişmesine neden olmuştur. Geleneksel dört eyvanlı şema terk edilmiş, iki katlı evler ve ilk kooperatif mahalleleri inşa edilmeye başlanmıştır (Şekil 17). Betonarmenin sağladığı olanaklar ile yapı hacminin de büyüdüğü görülmektedir. Kübik ev (Şekil 18 ve 19) tasarımı modern yaşamın simgesi haline gelmiştir. Modern konutların halk tarafından kabul görmesinin sağlanması doğrultusunda radyo yayınları ve dergiler aracılığıyla da idealize modern konut imgesi ortaya konulmaktadır (Akurgal, 1984, s. 31; Bilgin, 1996, s. 294; Bozkurt ve Altınçekiç, 2013, s. 76, 77; Koca, 2015, s. 22; Özcan, 2007, s. 297; Sözen, 1996, s. 17, Ülkü, 2018, s. 70; Yaldız ve Parlak, 2018, s. 4932).
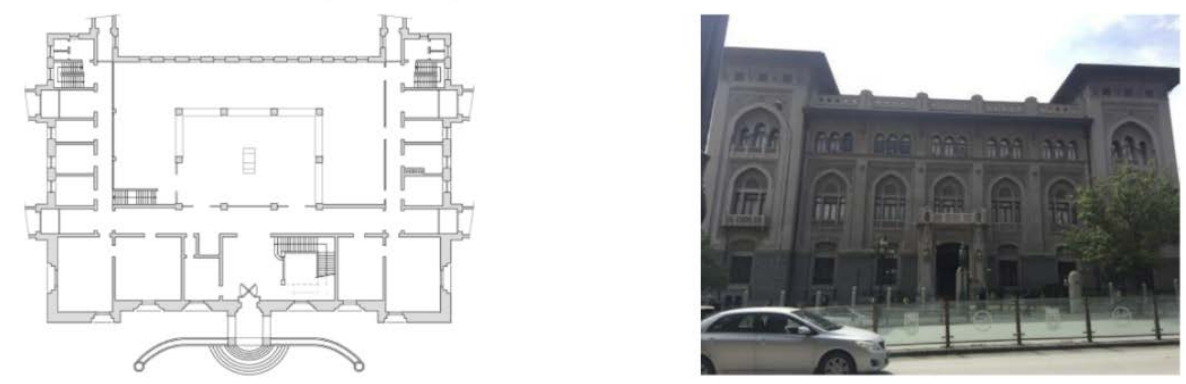

Şekil 15. Ziraat Bankası İdare Binası (Yaldız ve Parlak, 2018, s. 4932)

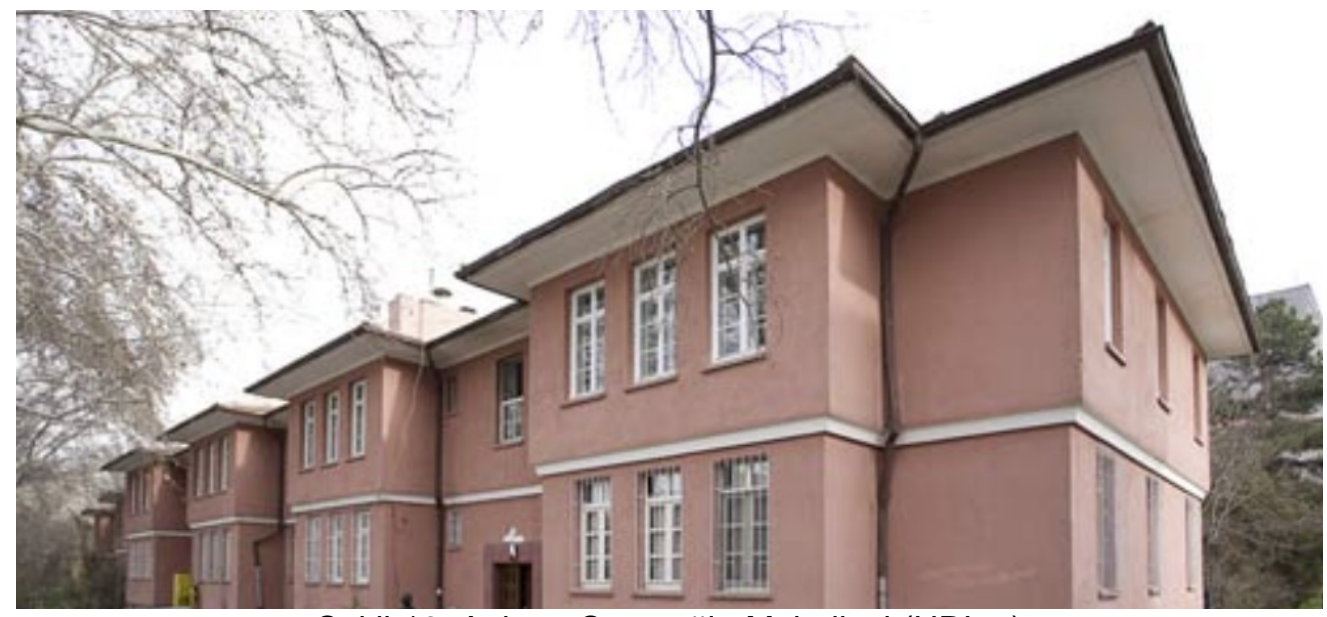

Şekil 16. Ankara Saraçoğlu Mahallesi (URL 7) 


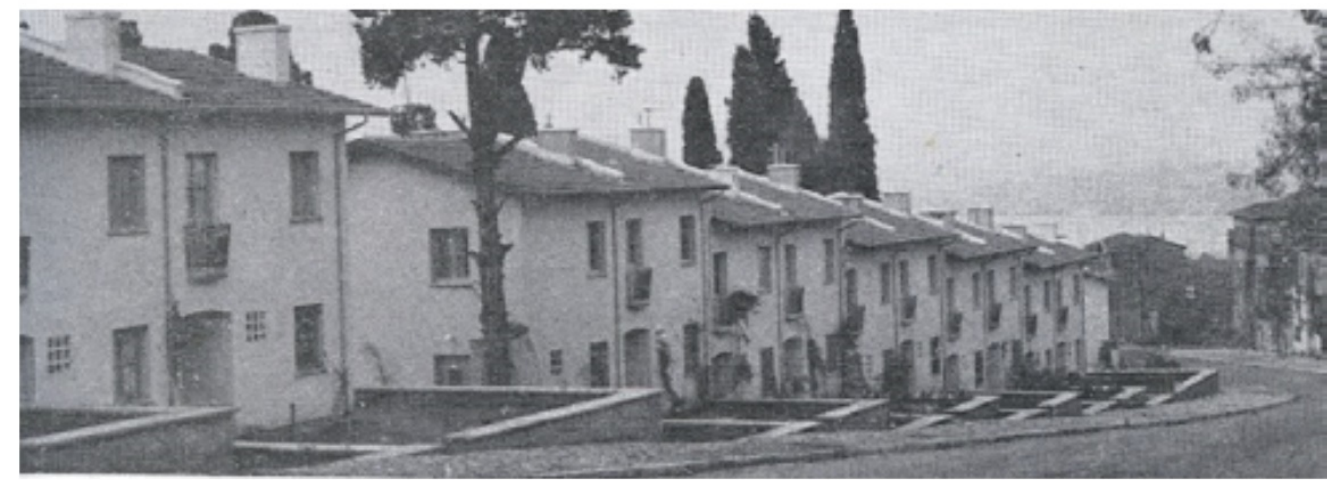

Şekil 17. Cumhuriyet döneminde İzmir'de Belediye Kooperatif Evleri (URL 8)
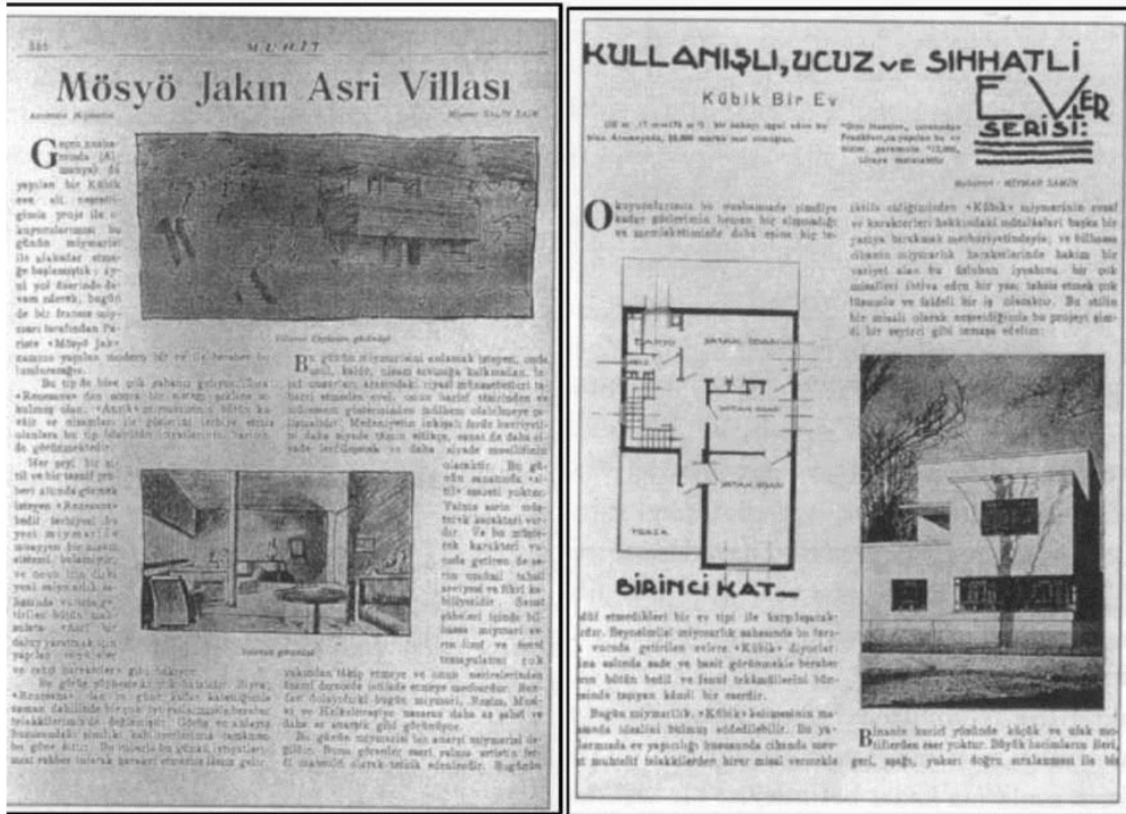

Şekil 18. Erken Cumhuriyet döneminde modernleşmenin simgesi kübik ev (Ülkü, 2010, s. 71)

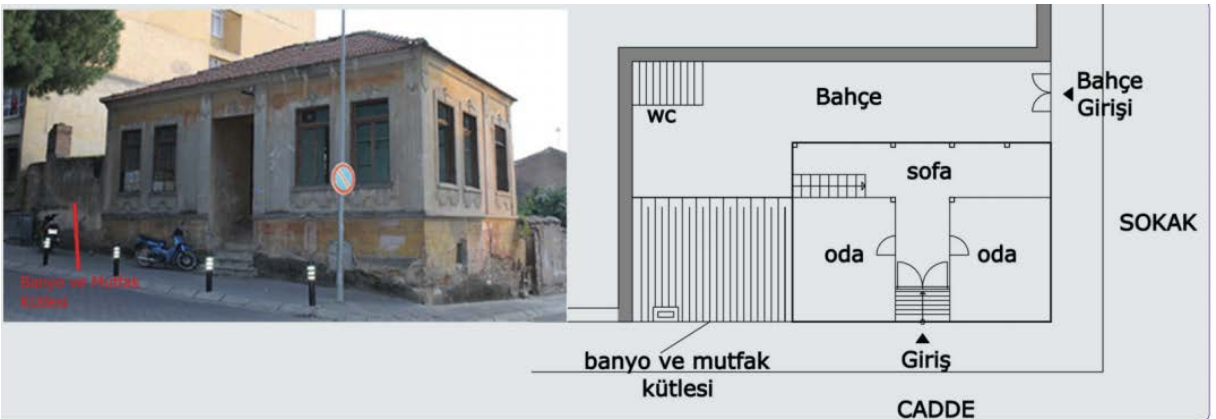

Şekil 19. Erken Cumhuriyet dönemi konut şeması (Şimşek, 2015, s. 49)

\subsection{0-1980: Plansız Kentleşme Dönemi}

1950'li yıllarla başlayan ve 1980'lere kadar süren dönem ise plansız bir kentleşmenin söz konusu olduğu dönem olarak ele alınabilir (Koca, 2015, s. 23). 1950’ler, Türkiye'de kırdan kente göç olgusunun ortaya çıkmaya başladığı bir dönem olmuştur. Bu tarihe kadar hızlı bir kentleşme olgusu söz konusu değilken; tarımda makineleşme ile kırda işsiz kalan nüfus, sanayide çalışmak için özellikle büyükşehirlere göç etmiştir. 1950 itibariyle kentlerde iki katlı, yığma, her katı konut olan yapılar artmaya başlamış, bu 
yapılarda tuğla ve beton kullanılmıştır. Kamunun konut arzının kente yeni gelenlerin barınma intiyaçlarını karşılamaya yetmemesi ile 1950'lerle beraber Türkiye gecekondu sorunu ile tanışmaya başlamıştır. Kentlerin çeperlerindeki kamuya ve özel kişilere ait arazilere izinsiz biçimde yapılan, köye benzer yapılar topluluğu olan gecekondular, önceleri masum barınaklar iken, uygulanan imar afları nedeniyle yaygınlaşmış ve zaman içinde imar hakkı elde edilerek apartmanlaşmalarıyla ticari değer kazanmışlardır. 1965 yılında yayımlanan Kat Mülkiyeti Kanunu ile betonarme apartmanlar (Şekil 20) giderek yaygınlaşmıştır (Keleş, 2013, s. 520; Bilgin, 1996, s. 294).

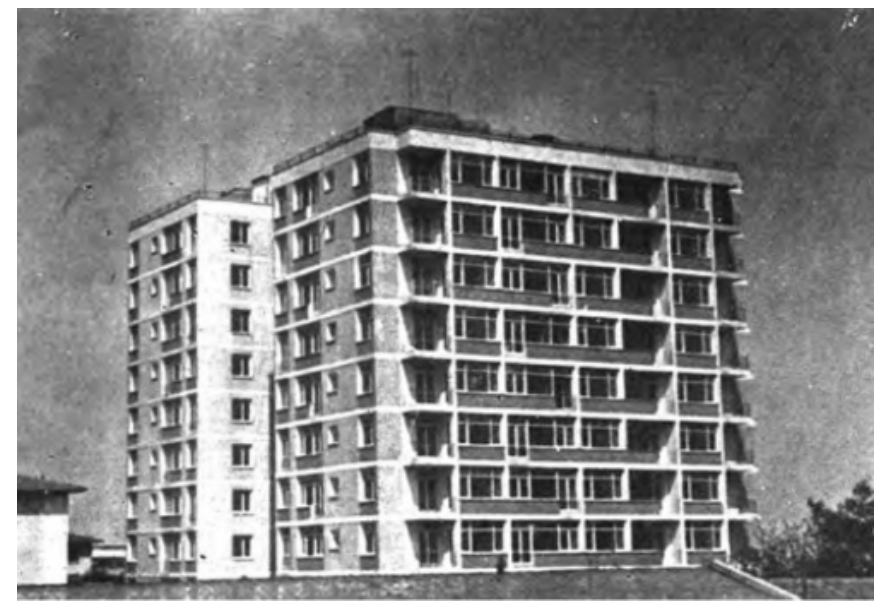

Şekil 20. 1965 Apartman bloğu örneği (Koca, 2015, s. 23)

\subsection{0-2000: Hızlı Kentleşme Dönemi}

1980 sonrası dönem ise hızı bir kentleşmenin görüldüğü dönem olmuştur. 24 Ocak Kararları doğrultusunda ekonomik yeniden yapılanma çerçevesinde küresel çapta olduğu gibi Türkiye'de de neoliberal politikalar uygulanmaya başlanmıştır. Büyükşehir belediyelerinin kurulması ve imar hakları konusundaki gelişmeler doğrultusunda kentsel mekânın çehresi oldukça değişmiş ve farklı mimari öğelerin bir arada olduğu, hızla büyüyen ve genişleyen bir hal almıştır. Bu süreçte kentlerde yeşil alan miktarında ciddi azalmalar olduğu ve bir dönemin mimari karakterini yansıtan sivil mimarlık örneklerinin ise yeni imar faaliyetlerinin yapılması doğrultusunda yıkıldığı görülmektedir. 1980 sonrası dönemde gecekondulaşma da yapısal bir sorun haline gelmiştir (Bozkurt ve Altınçekiç, 2013, s. 77; Keleş, 2013, s. 373, Koca, 2015, s. 26; Özcan, 2007, s. 298, Kültür Bakanlığı, 2002, s. 9). 1984 yılında yapılan düzenlemelerle düşük ve orta gelir grubunun konut sorunun çözümü için Toplu Konut İdaresi Başkanlığı (TOKI) kurulmuş ve toplu konut projeleri geliştirilmeye başlanmıştır (Şekil 21). Özellikle 90'lı yıllarla beraber özel sektörün toplu konut projelerine ayırdığı sermayenin arttığı görülmektedir (Koca, 2015, s. 28). Bu dönemin sonunda 1999 yılında yaşanan Gölcük depremi, 2000'li yıllarla birlikte Türkiye kentlerinde yerleşme ve konut yapısını ve bunlara ilişkin politikaları etkileyecek önemli değişimlerin başlamasında önemli rol oynamıştır (Kentleşme Şûrası, 2009, s. 27).
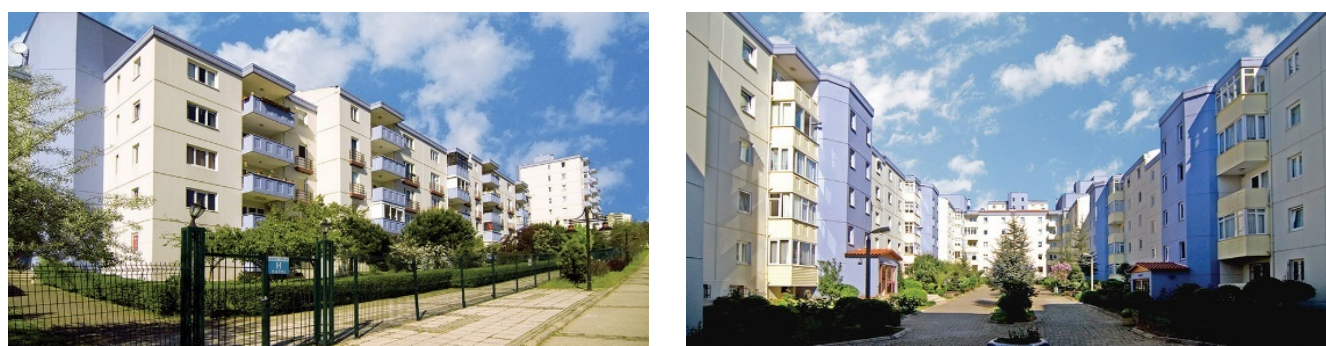

Şekil 21. TOKi Ataşehir Konutları-1993 (URL 9) 
Tarihsel Gelişim Süreci İçinde Anadolu'daki Yerleşimler ve Konut Tipolojileri Üzerine Bir Değerlendirme An Evaluation on Settlements and Housing Typologies in Anatolia within Historical Evolution Process

\subsection{0'den Günümüze: Kentsel Dönüşüm Dönemi}

2000 'li yıllarla birlikte kentsel gelişime ve konut üretim biçimine yön veren, odağında TOKI'nin olduğu ve kentsel dönüşüm projelerinin yoğun bir biçimde gerçekleştirildiği bir dönem başlamıştır. Yukarıda da ifade edildiği gibi, bunda 1999 yılında yaşanan Gölcük depreminin önemli etkisi olmuştur ve mevcut konut stokunun niteliği tartışılmaya başlanmıştır (Koca, 2015, s. 29; URL 10). Ayrıca 2005 yılında yayımlanan 5393 sayılı Belediye Kanunu, belediyelerin kentsel dönüşümün yerel ayağı olarak rol almalarını beraberinde getirmiştir. Kentsel dönüşüm ve yenileme çalışmalarına hız kazandıran diğer mevzuatlar ise, 5366 Sayılı Yıpranan Tarihi ve Kültürel Taşınmaz Varlıkların Yenilenerek Korunması ve Yaşatılarak Kullanılması Hakkında Kanun ve 2012 yılında yayımlanan 6306 sayılı Afet Riski Altındaki Alanların Dönüştürülmesi Hakkında Kanun olmuş ve Türkiye kentlerindeki yerleşim ve konut tipolojisi üzerinde önemli sonuçlar ortaya çıkarmışlardır (Keleş, 2013, s. 389; Kentleşme Şûrası, 2009, s. 27; URL 10, URL 11).

Bugünün kentlerinde hemen tüm donatıların kendi içinde yer aldığı, içe dönük konut siteleri giderek yaygınlaşmaktadır (Polat ve Kartal, 2018, s. 68). Çağdaş yapı malzemeleri olarak nitelenen çelik, betonarme, cam, gaz beton, çeşitli seramikler ve türevleri tüm kentlerdeki yapılarda kullanılmakta ve giderek şekli birbirine benzeyen ve özgünlüklerini yitiren kentleri ortaya çıkarmaktadır. Günümüzde kentlerdeki tarihi dokular, modern çağın intiyaçlarını karşılayamadıkları gerekçesiyle bakımsız bırakılarak terk edilmekte ve yaşanan değer kaybı nedeniyle kentsel çöküntü alanları haline gelmektedirler. Buralarda değişen kullanıcı profili ise zaten beton bloklar arasında terkedilmiş ve bozulmuş tarihi dokuya bir nevi son darbeyi vuran bir etken olmaktadır. Ayrıca kentlerde doğru biçimde uygulanmayan koruma politikaları ise bu dokuların bilinçli olarak yok edilmesi ve tahrip edilmesi sonucunu ortaya çıkartmaktadır. Tüm bu sorunların temeline bakıldığında esasen konunun bilinçsizlik olduğu görülmektedir. Bu bakımdan,1950'li yıllardan günümüze önemli şekilde tahrip edilmeye devam edilen kültürel ve doğal mirasın, yerel kültürel kimliğin ve zenginliğin korunmaları ve kentlilerin aidiyet duygusunun geliştirilmesi doğrultusunda söz konusu koruma süreçlerine kentlilerin, merkezi yönetimin ve yerel yönetimlerin, akademisyenlerin ve sivil toplum kuruluşlarının yani özetle, ilgili tüm paydaşların daha fazla ve etkin şekilde dahil edilmesi ve kültürel ve doğal miras bilincinin geliştirilmesi günümüzde oldukça önemli bir konu haline gelmiştir (Arabacıoğlu ve Aydemir, 2007, s. 206; Negiz, 2017, s. 168).

\section{Değerlendirme ve Sonuç}

İnsanlık var olduğundan bu yana sürekli içinde yaşadığı ortamla etkileşim halinde olmuştur. Tarihsel gelişim süreci içinde bu ilişkinin seyrini değiştiren bazı önemli kırılma noktaları ortaya çıkmıştır. Şüphesiz bunlardan en önemlilerinden biri insanların Neolitik dönemde yerleşik hayata geçmesidir. Bu insanlık adına daha ileri bir gelişme için uygun şartların oluşmasını sağlamış ve bundan sonraki süreçteki gelişmeler, yerleşikliğe geçmenin önemini gözler önüne sermiştir. Kent sosyoloğu Robert Park, kentleri insanlığın en müthiş eserleri ve uygarlığın atölyesi olarak nitelendirmektedir. Kentler, yeniliklerin ve kültürlerin kaynağıdır. Bu çalışma kapsamında tarih öncesi çağlardan başlayarak günümüze kadar gelen süreçte Anadolu kentlerinin yapısı ve konut tipolojisi, etkileşim halinde olduğu kültürlerle bir arada ele alınmış ve bu etkileşimin de katkısıyla yaşanan gelişmeler, değişimler ve farklılaşmalar dönemler halinde değerlendirilmiştir. 
Anadolu'da Paleolitik dönemdeki avcı-toplayıcı ve yerleşik düzene henüz geçilmemiş dönemden kademeli olarak M.Ö. yaklaşık 10.000'lerde Neolitik dönemde yerleşik düzene geçilmiş ve bu geçişe inanç sistemindeki gelişmenin öncülük ettiği görülmüştür. İnsanları belli bir noktada ve kalıcı bir tapınak inşa etmeye iten güç, onu mağaralardan köy yaşantısına taşımıştır. Bu geçişin sağladığı avantajlar insanlığın gelişimi bağlamında iyi bir biçimde değerlendirilmiş, köyler evirilerek kentler oluşturulmuştur. Anadolu'nun bu kapsamda en çok etkileşim içinde olduğu medeniyetlerden biri, aynı zamanda topraklarının bir kısmı Anadolu'da olan Mezopotamya olmuş ve şehir devrimini gerçekleştiren Mezopotamya, sırlı tuğla kullanımı gibi malzeme bilgisini Anadolu'ya aktarmıştır. Gerek Mezopotamya'da gerek Anadolu'da bu dönemde konutlarda kullanılan yapı malzemesi bölgelere göre taş, tuğla, kerpiç olarak değişiklik gösterse de kent dokusunun ızgara şemaya oturduğu görülmüştür.

İlk Tunç çağında Anadolu'da megaron tipi yapılaşma, sonraki konut yapımını karakterize etmiş ve yapı malzemesi ile form arasındaki ilişkiyi gözler önüne seren önemli bir örnek teşkil etmiştir.

Söz konusu plan şeması ve megaron tipi yapılaşma etkilerini Hitit ve Frigler'de de göstermiş, ardından Antik Dönem'e gelindiğinde de Anadolu'da kurulan koloni kentlerinde gridal kent formu ve megaron yapı iyice yerleşmiştir. Ancak gridal formun uygulanması konusunda şüphesiz en önde gelenler Roma'ıllar olmuş ve ızgara şemayı tüm Roma kentleri için standart olarak belirlemişlerdir. Roma kentlerinde megaron, domusa dönüşürken, yanı sıra çok katlı apartmanlar olan insulalar da inşa edilmiştir.

Roma İmparatorluğu'nun M.Ö. 395'te ikiye ayrılması, Anadolu'da yerleşim yerleri ve konut dokusu bağlamında önemli bir değişimi beraberinde getirmiştir. Orta Çağ'da derebeylikleri kurulmuş ve sur içinde kendine dönük kentler ortaya çıkmıştır. Orta Çağı'ın Anadolu yüzünde Bizans Dönemi boyunca Roma'nın intişamını oluşturan tüm kentsel unsurlar terk edilmiş, ızgara şemadan vazgeçilerek yerini organik şemaya bırakmış ve deyim yerindeyse konut kalitesi bağlamında bir taşralaşma söz konusu olmuştur.

11. yüzyılda Orta Asya'dan Anadolu'ya gelen Türkler, Anadolu'nun kültür mozaiğine, yerleşim dokusuna ve konut tipolojisine farkı bir boyut kazandırmış, temeli Orta Asya'ya ve göçebeyken kullandıkları çadırların yerleşimine ve ortak mekân kurgusuna dayanan dört eyvanlı şemayı, Anadolu'da karşılaştıkları kültürel birikimle harmanlayarak yeni bir konut tipolojisini Anadolu'ya ve çevredeki medeniyetlere kazandırmışlardır. Selçuklu ve sonrasında Osmanlı'da bu tipoloji devam ettirilmiştir. 13. yüzyılda Anadolu'daki kentlerin gelişiminde ticaret etkili olmuş ve bu nedenle kentlerde dış kale ortadan kalkmaya başlamıştır.

Osmanlı'da erken dönemde yerleşme sisteminin kuruluş aşaması 14. yüzyıl sonundan 15. yüzyılın ikinci yarısına dek sürmüştür. Bizans kenti çevresine kurulan yerleşimler zamanla büyüyerek bütünleşip, topografya ile uyumlu organik formlar ortaya koymuşlardır. Yerleşimde doğaya saygı temel alınmıştır. 15. yüzyılda Fatih Sultan Mehmed döneminden başlayarak Anadolu kıyılarında limanları korumak doğrultusunda yeni kaleler inşa edilmiştir. Ancak bu dönemde surlarla çevrili kent yapısına çok seyrek rastlanmaktadır. Osmanlı'da Geleneksel/Klasik dönem 16. yüzyıldan başlayarak 18. Yüzyıl sonuna kadar sürmüş, kentlerdeki çeşitlilik sadece fonksiyonlarda değil, etnik, dini, ekonomik ve sosyal yapıda da kendini göstermiştir. Kentlerin yerleşim dokusu organiktir, arazinin doğal eğime göre kıvrılan sokaklar dardır ve bazen de çıkmaz sokak oluşumları görülmektedir. Geleneksel Türk evlerine bakıldığında ise plan tipi, sofa türü, kullanılan yapım malzemesi ve bulunulan coğrafi bölge gibi sayıları artırılabilecek pek 
çok unsura dayalı sınıflamaların yapıldığı görülmektedir. Bu dönemde Anadolu'da yapılarda kullanılan malzemeler ahşap, taş ve kerpiç olmuştur. 19. yüzyıla kadar kentsel yerleşmelerde gridal yerleşme dokusuna dönülmemiş ve bölgesel malzeme ve diğer özelliklere göre farklılaşsa da genel unsurlar bakımından ortaklıkları olan bir Türk evi tipolojisi oluşturulmuştur.

19. yüzyıla gelindiğinde ise Klasik Osmanlı kentlerinde demiryollarının gelişimi, kent elitlerinin bu kent formunu yerleşmeye daha uygun bulması ve eski dokunun yangınlarla yok olması gibi pek çok nedenle ve 1839 Tanzimat Fermanı'nın getirdiği batılılaşma etkisiyle önemli değişimlerin görülmeye başlandığı bir dönem başlamıştır. Kentlerde hem gridal hem de organik dokunun bir arada görüldüğü ikili yapı söz konusu olmuştur. Bu ikili yapı, yabancı mimarların da etkisiyle Cumhuriyetin ilanından sonraki dönemde de sürmüştür. Yine bu dönemde İstanbul'un bazı semtlerinde ilk defa apartmanların yapılmaya başlandığını, geleneksel konut yapısının giderek terkedildiği, bunda da dönemin çağdaşlaşma ve modernleşmeyi eş tutan yaklaşımlarının etkisiyle yaşanan toplumsal dönüşümün bir sonucu olarak, kalabalık ailelerden çekirdek aile yapısına dönüşün etkisi olduğunu söylemek mümkündür.

Cumhuriyetin ilanı ile Ankara'nın tüm Anadolu kentleri için prototip olarak imar edildiği dönemde yukarıda da değinilen ikili yapı yabancı mimarların etkisiyle sürmüş ancak 1950'lere dek hızlı bir kentleşme olgusu görülmemiştir. 1950'li yıllarla beraber Anadolu kentlerinde tarımda makineleşme sonucunda işsiz kalan nüfusun büyükşehirlerdeki yeni kurulan sanayilerde çalışmak üzere kırdan kente göç etmesi ise yeni bir dönemi başlatmıştır. Kamunun konut arzının yetersiz olması, özellikle büyükşehirleri gecekondular ile tanıştırmış ve ilerleyen süreçte gecekondulara getirilen imar afları 1980'lerde sorunun boyutlarını artırmıştır. Şüphesiz gecekonduları masum barınaklardan bir yatıım aracına götüren ve kentleri 1980 sonrasında hızlı bir yapılaşma ve yayılmaya iten en önemli unsurlardan biri Türkiye'de de uygulanmaya başlanan neoliberal ekonomi politikalarıdır. Bu süreçte kentlerdeki önemli sivil mimarlık örnekleri yıkılmış ve korunması gerekli kültürel doku zarar görmüştür.

Günümüz kentlerinde kentsel yayılma ve nüfus artışı ile birlikte görülmeye devam etmektedir. Bu karmaşık yapının içinde belirli bir yerleşim planı şeması yoktur ve eklektik ve çok parçalı bir kentleşme dokusu göze çarpmaktadır. Apartmanlar ve gökdelenler ile yerel kimliğin ve yerel mimari ve malzeme öğelerinin geri plana atıldığı günümüz kentlerinde temel sorun birbirine benzer yapılaşmaların görülmesi ve kentlerin özgün değerlerini yitirmesidir. Günümüz kentleşme ve konut dinamiklerini etkileyen bir diğer unsur da 2000'li yıllarla birlikte yaşanan büyük deprem kayıpları sonrasında mevut konut stokunun kalitesinin ve miktarının sorgulanması sonucu ortaya çıkan ve odağında TOKI'nin yer aldığı kentsel dönüşüm sürecidir.

Çalışmada yukarıda belirtilen hususlardan ve bulgulardan hareketle yapılan değerlendirmede;

- Anadolu topraklarında yerleşme deseninin ve konut tipolojlerini belirleyici unsurların bölgesel olarak değişen coğrafi, iklimsel, kültürel, ekonomik ve fiziksel koşullar olduğu,

- Neolitik dönemden 19. yüzyıla gelene kadarki süreçte Anadolu'da hüküm süren farklı medeniyetler tarafından dönemsel olarak gridal (ızgara) yerleşim deseninin, yine dönemsel olarak bazen de organik kent formunun hâkim olduğu, 
- Ancak Anadolu kentlerinde 19. yüzyıl itibariyle yerleşimlerde bu yapının ikisinin birden görülmeye başlandığı ve bu ikili yapının etkilerinin konut tipolojisine de yansıdığı ve Cumhuriyet dönemine de sirayet ettiği,

- Günümüzde gelinen koşullarda ise, kentsel mekân ve onun içinde konutun değişen toplumsal, çevresel ve ekonomik koşullar dolayısıyla daha parçalı ve eklektik yapıyı yansıttığı,

- Bu karmaşık ve eklektik yapı içinde benzer yapım teknikleri ve malzeme kullanımı nedeniyle kentlerin giderek birbirine benzediği,

- Sosyal ve kültürel kimlik ve toplumsal aidiyet duygusu bağlamında önemli unsurlar olan kültürel varlıkların korunmasının ve bu yönde toplumsal farkındalığın geliştirilmesinin ise bu koşullarda daha da önem kazandığı, elde edilen önemli sonuçlardır.

2019 yılında düzenlenen Katılımcı Akhisar Eski Belediye Meydanı ve Yakın Çevresi Ulusal Mimarlık ve Kentsel Tasarım Fikir Yarışması kapsamında hazırlanan Rapor'da yer alan Şekil 22'de geçmişten günümüze Anadolu kentlerindeki değişimi ve günümüzde gelinen durumu özetlemesi bakımından bu çalışmanın sonunda yer verilmiştir.

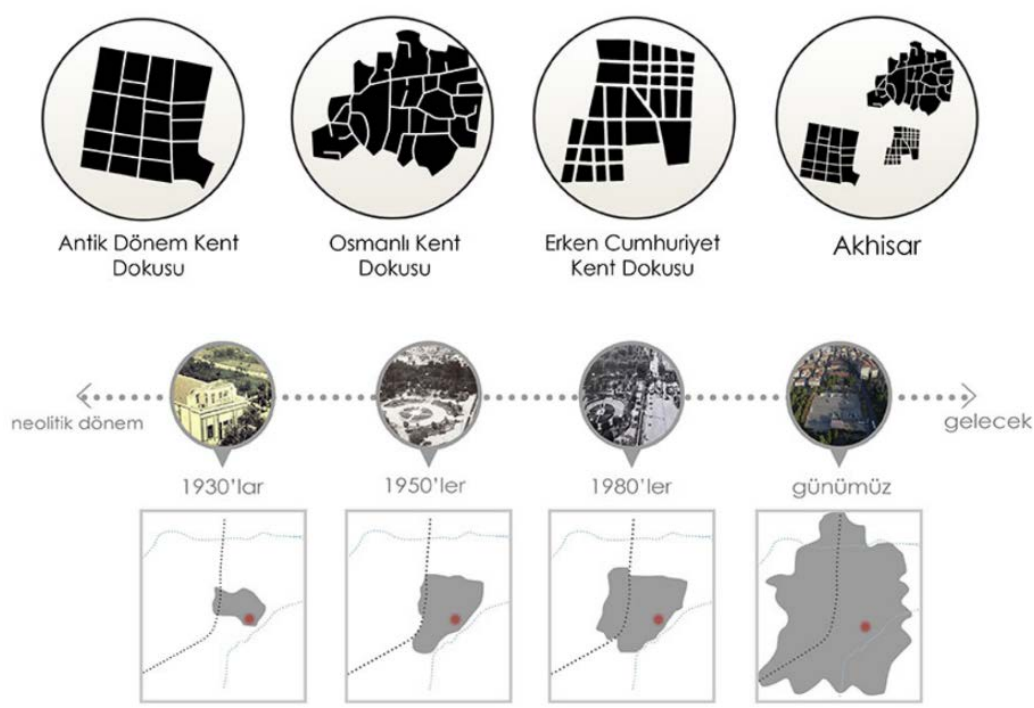

Şekil 22. Geçmişten günümüze Akhisar (URL 12).

Günümüzde kentleri ve onun içinde geçmişten bugüne aktarılan önemli kentsel dokuları ve tarihi konutları etkileyen çok sayıda tehdit söz konusudur. Sadece kentlerdeki dönüşüm baskısı değil, bunlar yanında iklim değişikliği başta olmak üzere çevresel sorunlar ve bunlara bağlı olarak gelişen afetler, söz konusu kültür varlıkları için önemli olumsuz etkiler ortaya çıkarmaktadır. Geçmiş geleceğe yön vermek doğrultusunda değerli bir kaynaktır ve kentler yaşayan bir organizma olarak ele alınmalıdır. Bu kadim toprakların geçmişine ait izlerin dönem farkı gözetilmeksizin korunması yönünde adımlar atmak ve bunları gelecek kuşaklara taşımak şimdi her zamankinden önemli hale gelmiştir. Anadolu'nun dünya tarihindeki yeri düşünüldüğünde kültürel ve doğal varlıkların tüm unsurlarına karşı neden daha duyarlı olunması gerektiği kendiliğinden ortaya çıkmaktadır. 
Tarihsel Gelişim Süreci İçinde Anadolu'daki Yerleşimler ve Konut Tipolojileri Üzerine Bir Değerlendirme An Evaluation on Settlements and Housing Typologies in Anatolia within Historical Evolution Process

\section{Kaynaklar}

Abbasoğlu, H. (1996). Anadolu'da antik çağda konut. Yıldız. Sey (Der.).Tarihten günümüze Anadolu'da konut ve yerleşme içinde (ss. 44-81). İstanbul: Türkiye Ekonomik ve Toplumsal Tarih Vakfı.

Acıoğlu, Y. (2014). Kubad Abad sarayı alçı buluntuları. Sanat Tarihi Dergisi, XXIII(2), 111.

Akurgal, E. (1984). Ulusal mimarlığın yeniden doğuşu. Mimaride Türk milli üslubu semineri içinde (s.31-33). İstanbul: Kültür ve Turizm Bakanlığı Eski Eserler ve Müzeler Genel Müdürlüğü.

Akurgal, E. (1990). Anadolu uygarlıkları (10. bs.). İstanbul: Net Turistik Yayınlar.

Aliağaoğlu, A. ve Uğur, A. (2016). Osmanlı şehri. SDÜ Fen Edebiyat Fakültesi Sosyal Bilimler Dergisi, 38, 203-226.

Arabacıoğlu, P. ve Aydemir, I. (2007). Tarihi çevrelerde yeniden değerlendirme kavramı. Megaron, 2(4), 204-212.

Arslan, G. (2016). Demir Çağ’da Anadolu kent kapıları (Yüksek Lisans Tezi). Çorum: Hitit Üniversitesi, Sosyal Bilimler Enstitüsü Arkeoloji Anabilim Dalı.

Atila, N. (2018). Hitit Devleti'nde güvenlik algısı. Ankara Üniversitesi Dil ve TarihCoğrafya Fakültesi Tarih Bölümü Tarih Araştırmaları Dergisi, 37(64), 161-190.

Azezli, G. (2009). 19.yy'da Osmanlı konut mimarisinde iç mekân kurgusunun Safranbolu evleri örneğinde irdelenmesi (Yüksek Lisans Tezi). İstanbul: İstanbul Kültür Üniversitesi, Fen Bilimleri Enstitüsü Sanat ve Tasarım Fakültesi.

Bakırer, Ö. (1981). Selçuklu öncesi ve Selçuklu dönemi Anadolu mimarisinde tuğla kullanımı. Ankara: ODTÜ.

Bakırer, Ö. (2017). Reflections of the "naked brick style" in Seljuk Anatolia. Selçuklu Medeniyeti Araştırma Dergisi, 2, 193-225.

Baş, A. ve Dursun, Ş. (2017). Keykubadiye sarayı 2014 yılı sondaj çalışması. XX. Uluslararası Ortaçağ ve Türk dönemi kazıları ve sanat tarihi araştırmaları sempozyumu bildirileri içinde (ss. 87-105). Sakarya: Sakarya Üniversitesi Yayınları.

Bayazıt, N. (2014). Safranbolu evlerinin plan tipolojisi ve kullanıcı ihtiyaçları hiyerarşisi. Tasarım ve Kuram, 17, 1-15.

Bilgin, İ. (1996). Radikal modernleşme. Yıldız Sey (Der.), Tarihten günümüze Anadolu'da konut ve yerleşme içinde (ss. 294-310). İstanbul: Türkiye Ekonomik ve Toplumsal Tarih Vakfı.

Bozkurt, S. G. ve Altınçekiç, H. (2013). Anadolu'da geleneksel konut ve avluların özellikleri ile tarihsel gelişiminin Safranbolu evleri örneğinde irdelenmesi. İstanbul Ormancılık Fakültesi Dergisi, 63(1), 69-91. 
Catanese, A.ve Snyder, J. (1988). Introduction to urban planning, New York, NY: McGrow Hill Company.

Ceylan, B. (2004). Antik dönem Anadolu kentler ve kent mimarisi: Antik kentlerde kent ve yapı etkileşimi. Bursa yapı yaşam kongresi bildirileri içinde 1-10. Bursa.

Childe, G. (2009). Tarihte neler oldu? Araçların öyküsü (5.bs.). (A. Şenel ve M. Tunçay, Çev.). İstanbul: Kırmızı.

Deniz, B. (2007). Orta Asya'daki eski Türk evleri. Akdeniz Üniversitesi Güzel Sanatlar Fakültesi Akdeniz-Sanat Dergisi, 1(1), 17-55.

Eisner, S., Gallion, A. ve Eisner S.(1963). The urban pattern. New York: D. Pinceton Van Nostrand Reinhold.

Eldem, S. H. (1954). Türk evi plan tipleri. İstanbul: İstanbul Teknik Üniversitesi Yayınları.

Eruzun, C. (1987). Konut üretiminde nitelik sorunu. Mimarlık Dergisi, 5-6, 48-50.

Göğebakan, Y. (2015). Karakteristik bir değer olan geleneksel Türk evinin oluşumunu belirleyen unsurlar ve bu evlerin genel özellikleri. Inönü Üniversitesi Kültür ve Sanat Dergisi, 1(1), 41-55.

Gözlü, A. (2015). Antik Yunan'da (Hellen) koloniler ve bunların nitelikleri. Uluslararası Kıbrıs Üniversitesi Folklor/Edebiyat Dergisi, 21(81), 179-190.

Günay, B. (2012). Izgara kent tasarımı. M. Ersoy (Der.), Kentsel planlama ansiklopedik sözlük içinde (ss.179-190). İstanbul: Ninova.

İşler, B. (2013). Orta Likya'da erken Bizans dönemi yerleşimleri ve kırsal konut mimarisi. Adalya, 16, 287-304.

Karaca, Ö. (2020). Anadolu evlerinin mimari gelişimi. Mecmua-Uluslararası Sosyal Bilimler Dergisi, 5(10), 320-344.

Kavas, R. K. (2012). Türk konut mimarisinde tarihsel süreklilikler: Orta Asya ve Anadolu. Belleten, 76(276), 503-526.

Kejanlı, T. (2010). Anadolu'da Selçuklu ve Osmanlı dönemlerinde kent sistemi, kale ve merkez-çarşı gelişimi. New World Science Academy, 5(3), 287-302.

Keleş, R. (2013). Kentleşme politikası (15.bs.). Ankara: İmge Kitapevi.

Kentleşme şûrası kentsel dönüşüm konut ve arsa politikaları komisyonu raporu (2009). Ankara: Bayındırlık ve İskân Bakanlığı.

Koca, D. (2015). Türkiye'de çağdaş konut üretiminin yeniden okunması. Tasarım ve Kuram, 19, 19-36.

Konyar, E. (2021). Anadolu ve Mezopotamya tarihi. İstanbul: İstanbul Üniversitesi. 
Tarihsel Gelişim Süreci İçinde Anadolu'daki Yerleşimler ve Konut Tipolojileri Üzerine Bir Değerlendirme An Evaluation on Settlements and Housing Typologies in Anatolia within Historical Evolution Process

Kuban, D. (1966). Türkiye'de malzeme koşullarına bağlı geleneksel konut mimarisi üzerinde bazı gözlemler. Mimarlık, 36, 15-20.

Kuban, D. (2002). Türk evi geleneği üzerine gözlemler Türk ve İslam Sanatı üzerine denemeler. İstanbul: Arkeoloji ve Sanat Yayınları.

Kültür Bakanlığı (2002). Türkiye'de tarihi kent dokularının korunması ve geleceğe taşınması sempozyumu. Antalya: Kültür Bakanlığı.

Mumford, L. (2013). Tarih boyunca kent (5.bs.). (G. Koca ve T. Tosun, Çev.). İstanbul: Ayrıntı Yayınları (Orijinal eserin yayın tarihi 1773).

Negiz, N. (2017). Kentlerin tarihsel sürdürülebilirliğinde kültürel miras: önemi ve değeri üzerine düşünmek. Akademia Sosyal Bilimler Dergisi, 3(1),159-172.

Ökmen, M. ve Yılmaz, A. (2009). Klasik dönemden Tanzimat'a Osmanlı kenti ve yerel yönetimler. Dumlupınar Üniversitesi Sosyal Bilimler Dergisi, 23, 91-112.

Özcan, Z. (2007). Anadolu konut yerleşim deseninde ikili oluşum Ankara BatıkentErgazi örneği”, Gazi Üniversitesi Mühendislik Mimarlık Fakültesi Dergisi, 22(2), 295306.

Özdemir, M. (2017). Neolitik dönem Anadolu mimarisinden bir kesit: Çayönü. Tarih ve Gelecek Dergisi, 3(3), 248-265.

Özdöl, S. (2011). Çanak Çömleksiz Neolitik Çağ'da Güneydoğu Anadolu'da din ve sosyal yapı. Tarih Incelemeleri Dergisi, 26(1), 173-199.

Öztürk Z. K. ve Şimşek, A. (2019). Tarih öncesi dönemdeki ilk barınma alanları ile Anadolu'daki Körtik Tepe, Hallan Çemi, Nevali Çori ve Aşıklı Höyük yerleşimlerinde, inanç ve kültürün etkisinin incelenmesi. İstanbul Sabahattin Zaim Üniversitesi Fen Bilimleri Enstitüsü Dergisi, 1(3), 14-22

Salihoğlu, T. (2021). KKTC'de Kırsal alan yerleşimlerine dayalı konut üretimi için bir model (Doktora Tezi). Lekoşa: Yakın Doğu Üniversitesi Fen Bilimleri ve Sosyal Bilimler Enstitüsü Mimarlık Anabilim Dalı.

Salihoğlu, E. F. ve Demirarslan, D. (2018). Hitit uygarlığında büyük tapınak mimarisi ve etkileri, Hitit Üniversitesi Sosyal Bilimler Enstitüsü Dergisi, 11(3), 1761-1779.

Solmaz, S. A. (2019). Turizmin doğuşu: sosyolojik bir olgu olarak turizm nasıl ortaya çıktı?". International Journal Of Social Humanities and Administrative Sciences, 5(19), 867-882.

Sözen, M. (1996). Cumhuriyet dönemi Türk mimarisi. Ankara: İş Bankası Kültür Yayınları.

Sözen, M. ve Eruzun, C. (1992). Anadolu'da ev ve insan. İstanbul: Emlak Bankası Yayınları.

Sözen, M. ve Tanyeli, U. (2014). Sanat kavram ve terimleri sözlüğü. İstanbul: Remzi Kitabevi. 
Şahinalp, M. S. ve Günal, V. (2012). Osmanlı şehircilik kültüründe çarşı sisteminin lokasyon ve çarşı içi kademelenme yönünden mekânsal analizi. Milli Folklor, 24(93), 149-168.

Şimşek, G. (2015). Aydın'da mimarlık mirası olarak cumhuriyet dönemi konutları. Megaron, 10(1), 43-56.

Öz, M. (2005). Osmanlı klasik döneminde Anadolu kentleri. Türkiye Araştırmaları Literatür Dergisi, 3(6), 57-88.

Polat, Y. ve Kartal, M. (2018). Cumhuriyetten günümüze Türkiye'de modernleşme bağlamında dışa kapalı konut üretimi. Aksaray Üniversitesi Iktisadi ve Idari Bilimler Fakültesi Dergisi, 10(4), 63-76.

Tekeli, İ. (2001). Modernite aşılırken kent planlaması. Ankara: İmge Kitabevi.

Tekin, M. (2017). Dünya tarihinde ilk şehir ve şehir devletinin ortaya çıkışı ve gelişimi", Gaziosmanpaşa Üniversitesi Sosyal Bilimler Araştırmaları Dergisi, 12(2), 17-30.

Tekkanat, S. S. ve Türkmen, S. N. (2012). Tarih boyunca kent formlarının biçimlenişi üzerine bir inceleme. Aksaray Üniversitesi Iktisadi ve Idari Bilimler Fakültesi Dergisi, 10(4), 107-124.

Tunay, İ. (1997). Bizans dönemi İstanbul evleri. Engin Akyürek (Der.) Sanatın Ortaçağı Türk, Bizans ve Batı sanatı üzerine yazılar içinde (ss.100). İstanbul: Kabalcı Yayınevi.

Ülkü, G. K. (2018). Konutun cinsiyeti. Süleyman Demirel Üniversitesi Mimarlık Bilimleri ve Uygulama Dergisi, 3(2), 62-80.

Ünsal, V. (2020). Paleolitik ve Neolitik Çağda Orta Kızılırmak Havzası. Uluslararası Sosyal Araştırmalar Dergisi, 13(71), 320-330.

Yariş, S. (2020). Geleneksel Türk evi mimarisinde Diyarbakır evlerinin yeri üzerine bir değerlendirme. Türkiyat Araştırmaları Enstitüsü Dergisi, 68, 313-340.

Yaldız, E. ve Parlak, Ö. (2018). Birinci ulusal mimarlık dönemi kamu yapıları. Social Sciences Studies Journal, 4(24), 4930-4947.

Yenel, S. (2012). Konut yerleşmelerinde değişimin irdelenmesi (Yüksek Lisans Tezi). İstanbul: İstanbul Teknik Üniversitesi, Fen Bilimleri Enstitüsü, Mimarlık Anabilim Dalı Mimari Tasarım Programı.

Ziya, G. (2000). Osmanlı kentinde kentsel form ve tasarım. Ege Mimarlık, 36, 31-33.

\section{İnternet Kaynakları:}

URL 1 http://auzefkitap.istanbul.edu.tr/kitap/tarih_ao/anadolumtarihi.pdf (Erişim Tarihi, 24.12.2020, saat- 23.30)

URL 2 https://avys.omu.edu.tr/storage/app/public/okay.peksen/137647/8.pdf (Erişim Tarihi, 12.12.2020, saat- 13.30) 
URL 3 http://www.kulturvarliklari.gov.tr/Eklenti/57316,catalhoyuk-neolitik-kenti-yonetimplanipdf.pdf?0 (Erişim Tarihi, 04.12.2020, saat- 15.00)

URL 4

http://catalhoyuk.ege.edu.tr/sites/default/files/CH\%202019\%20ARASTIRMA\%20RAPO RU_TR.pdf (Erişim Tarihi, 04.12.2020, saat- 16.30)

URL 5 https://avesis.yildiz.edu.tr/aerdem/dokumanlar (Erişim Tarihi, 24.12.2020, saat22.30)

URL 6 https://www.turkishnews.com/tr/content/2020/06/20/turk-evinin-evrimi/ (Erişim Tarihi, 04.12.2020, saat- 11.00)

URL 7 https://www.goethe.de/ins/tr/ank/prj/urs/geb/sie/sar/trindex.htm (Erişim Tarihi, 26.03.2021, saat- 10.30)

URL 8 http://kot0.com/erken-cumhuriyetin-yarim-kalmis-deneyi-isci-konutlari/ (Erişim Tarihi, 27.03.2021, saat- 10.30)

URL 9

http://www.bimcompany.com/tr/porje_detay.asp?katld=1\&durum=1\&projeld=14 (Erişim Tarihi, 27.03.2021, saat- 12.30)

URL10 https://www.toki.gov.tr/ kentsel-yenileme (Erişim Tarihi, 13.12.2020, saat07.30)

URL 11 https://www.resmigazete.gov.tr/eskiler/2012/05/20120531-1.htm (Erişim Tarihi, 12.12.2020, saat- 10.30)

URL 12 https://www.arkitera.com/proje/katilimci-akhisar-eski-belediye-meydani-veyakin-cevresi-ulusal-mimarlik-ve-kentsel-tasarim-fikir-yarismasi-2l (Erişim Tarihi, 11.12.2020, saat- 23.30) 